\title{
An overview of chemosynthetic symbioses in bivalves from the North Atlantic and Mediterranean Sea
}

\author{
S. Duperron ${ }^{1}$, S. M. Gaudron ${ }^{1}$, C. F. Rodrigues ${ }^{1,2}$, M. R. Cunha ${ }^{2}$, C. Decker ${ }^{3}$, and K. Olu ${ }^{3}$ \\ ${ }^{1}$ Université Pierre et Marie Curie, UMR7138 (UPMC CNRS IRD MNHN), Systématique, Adaptation, Evolution, 7, \\ quai St. Bernard, bâtiment A, 75005 Paris, France \\ ${ }^{2}$ Departamento de Biologia and CESAM, Universidade de Aveiro, Campus Universitário de Santiago, 3810-193 Aveiro, \\ Portugal \\ ${ }^{3}$ Laboratoire Environnement Profond, Département Etudes des Ecosystèmes Profonds, Centre Ifremer de Brest, BP 71, \\ 29280 Plouzané, France
}

Correspondence to: S. Duperron (sebastien.duperron@snv.jussieu.fr)

Received: 13 November 2012 - Published in Biogeosciences Discuss.: 26 November 2012

Revised: 16 April 2013 - Accepted: 18 April 2013 - Published: 14 May 2013

\begin{abstract}
Deep-sea bivalves found at hydrothermal vents, cold seeps and organic falls are sustained by chemosynthetic bacteria that ensure part or all of their carbon nutrition. These symbioses are of prime importance for the functioning of the ecosystems. Similar symbioses occur in other bivalve species living in shallow and coastal reduced habitats worldwide. In recent years, several deep-sea species have been investigated from continental margins around Europe, West Africa, eastern Americas, the Gulf of Mexico, and from hydrothermal vents on the Mid-Atlantic Ridge. In parallel, numerous, more easily accessible shallow marine species have been studied. Herein we provide a summary of the current knowledge available on chemosymbiotic bivalves in the area ranging west-to-east from the Gulf of Mexico to the Sea of Marmara, and north-to-south from the Arctic to the Gulf of Guinea. Characteristics of symbioses in 53 species from the area are summarized for each of the five bivalve families documented to harbor chemosynthetic symbionts (Mytilidae, Vesicomyidae, Solemyidae, Thyasiridae and Lucinidae). Comparisons are made between the families, with special emphasis on ecology, life cycle, and connectivity. Chemosynthetic symbioses are a major adaptation to ecosystems and habitats exposed to reducing conditions. However, relatively little is known regarding their diversity and functioning, apart from a few "model species" on which effort has focused over the last $30 \mathrm{yr}$. In the context of increasing concern about biodiversity and ecosystems, and increasing anthropogenic pressure on oceans, we advocate a better assessment of the diversity
\end{abstract}

of bivalve symbioses in order to evaluate the capacities of these remarkable ecological and evolutionary units to withstand environmental change.

\section{Introduction}

Bivalve mollusks occur in a variety of marine and freshwater ecosystems, at all depths and latitudes. Among other adaptations, they have evolved various strategies for nutrition, including filter-feeding using their gills, particle uptake using elongated labial palps, and carnivory through reduction of gills to muscular pumping elements. In some remarkable species (e.g., families Tridacnidae and Cardiidae), nutrition involves symbiotic interactions with micro-organisms such as photosynthetic dinoflagellates. Symbiotic nutrition through gill-associated bacteria is the most recently discovered nutrition mode. It was demonstrated in large clams and mussels found around deep-sea hydrothermal vents, first discovered in 1977 (Lonsdale, 1977). Scientists were puzzled when they discovered large fauna, including bivalves and giant tube worms around chimneys emitting high-temperature, toxic fluids. In fact, both bivalves and tube worms (Annelida: Siboglinidae) were shown to harbor chemoautotrophic bacteria in their tissues. These bacteria oxidize reduced sulfur from the fluids, and use the energy acquired to fix inorganic carbon, which is subsequently transferred to their animal host (Cavanaugh, 1983; Rau and Hedges, 1979). Similar, 
often related, organisms and symbioses were then identified at cold seeps and large organic falls occurring in the deep sea (Pailleret et al., 2007; Paull et al., 1984; Smith and Baco, 2003). Subsequent examples of symbioses have been found in much more readily accessible, reduced sediment habitats such as seagrass beds, mangroves, fjords, and deltas, and even in sewage sludge they have been since recorded (Dubilier et al., 2008; Fisher, 1990), illustrating the unexpected paths emerging scientific fields can follow. As will become evident in the following text, the term "symbiosis" must be interpreted in the broadest sense here, because isolating and evaluating costs and benefits for each partner is not an easy task (Douglas, 1994).

The occurrence of chemosynthetic symbioses is one of the characteristic features of cold seeps and hydrothermal vent faunas, because they are responsible for most in situ biological productivity and fuel the often high-biomass communities. That said, symbioses have often been overlooked in other habitats, in which symbiotic species tend not to be dominant and somewhat smaller. Nevertheless, the ability to associate with chemosynthetic bacteria is a recurring feature in the evolution of bivalves, since it has appeared independently in at least five families: the Mytilidae, Vesicomyidae, Solemyidae, Lucinidae and Thyasiridae. Recent discoveries of associated bacteria in two families (Nucinellidae and Montacutidae) suggest further species and habitats should be explored (Oliver and Taylor, 2012; Oliver et al., 2013). Tight evolutionary relationships exist between metazoans and their associated symbionts in various habitats, with several studies providing evidence that deep-sea vent and seep bivalve species originated from shallow-water ancestors (Craddock et al., 1995; Little and Vrijenhoek, 2003; Lorion et al., 2010; Williams et al., 2004). Examining the intra- and interspecific diversity of chemosynthetic symbioses in bivalves, within the context of functional, ecological, biogeographical and evolutionary trends in symbiotic systems, will provide greater insight into this adaptation to reducing habitats.

The Atlantic Ocean opened relatively recently ( 180 Mya), after fragmentation of Pangaea. Today, in the Northern Hemisphere, the Atlantic is connected with the Mediterranean Sea and the Gulf of Mexico. The Mediterranean only re-connected with the Atlantic following the Messinian salinity crisis (5.96-5.33 Mya), during which it essentially evaporated (Duggen et al., 2003). The Gulf of Mexico became exclusively connected to the Atlantic after the rise of the Isthmus of Panama about 3.1 Mya, restricting exchanges between the Pacific and Atlantic (Kegwin, 1978). In this context, the North Atlantic makes for an interesting area for investigating colonization, evolution and biogeography of chemosynthetic symbioses. Further, shallow-water coastal areas of the North Atlantic, Gulf of Mexico and Mediterranean have been investigated in detail for a long time, and the information regarding the diversity of bivalves is some of the most accurate available. On the continental shelf and in the deep sea, most of the sampling effort has focused on a relatively small number of areas subject to hot and cold venting, employing manned submersibles and remotely operated vehicles (Fig. 1). Many cold seep sites have been explored at varying depths in the Gulf of Mexico (see Cordes et al., 2010, for review), and several hydrothermal vents sites have been explored on the Mid-Atlantic Ridge (MAR) (Desbruyères et al., 2000; van der Heijden et al., 2012). Other areas have been less intensively investigated, such as deep hydrothermal vents in the Caribbean Sea (Piccard vent field, Mid-Cayman Ridge). Cold seeps are beginning to be explored in the Barbados prism, the east American margin (Blake Ridge), the Sea of Marmara, the eastern Mediterranean (Olimpi mud field, Anaximander mounds, Nile deep-sea fan), the Gulf of Cadiz (various mud volcanoes), the Norwegian margin (Haakon Mosby mud volcano and Storegga Slide), the Gulf of Guinea (Guiness, Regab, Kouilou), the Arctic margin (Loki's castle), the Caribbean Sea off Colombia, and the Laurentian deep-sea fan (Connelly et al., 2012; Cosel and Olu, 2009; Van Dover et al., 2003; Gebruk et al., 2003; Gracia et al., 2012; Olu et al., 1996; Olu-LeRoy et al., 2007a; Sahling et al., 2008, Cunha et al., 2013).

A survey of the literature indicates that approximately 200 bivalve species, in these areas, belong to families or subfamilies specifically reported to be associated with chemosynthetic bacteria. This number certainly underestimates the true diversity, as new species are often discovered upon exploration of new sites. Moreover, some presently described species could comprise several cryptic species, which are difficult to identify without detailed genetic study examining specimens in large quantities often not available for the deep sea. Such cryptic species have been documented in deep-sea Mytilidae (Jollivet et al., 1990; Jones et al., 2006; Lorion et al., 2010). Besides the problem of accurate species identification, the current taxonomic position of many chemosymbiotic bivalves is itself under debate. Genera were indeed often described morphologically at times when only very a few species were known. Many taxonomic characteristics have since lost their diagnostic value as the number of new available species increased, and new knowledge on features, such as allometric growth, became available. As a consequence, new molecular phylogenies frequently reveal polyphyly within genera (Decker et al., 2012; Jones et al., 2006; Krylova and Sahling, 2010; Taylor and Glover, 2006, Audzijonyte et al., 2012). Another problem is that many species have been described based on shell characteristics only, for which soft tissue is no longer available for validation by molecular techniques. Efforts are currently being made to connect "old" names (such as Idas modiolaeformis Sturany 1896) with recent molecular data, but ultimately a reassessment of bivalve taxonomy combining morpho-anatomical and molecular characteristics is needed (Lorion and Samadi, 2010). This must be kept in mind when dealing with the names of species and genera (Table 1). 


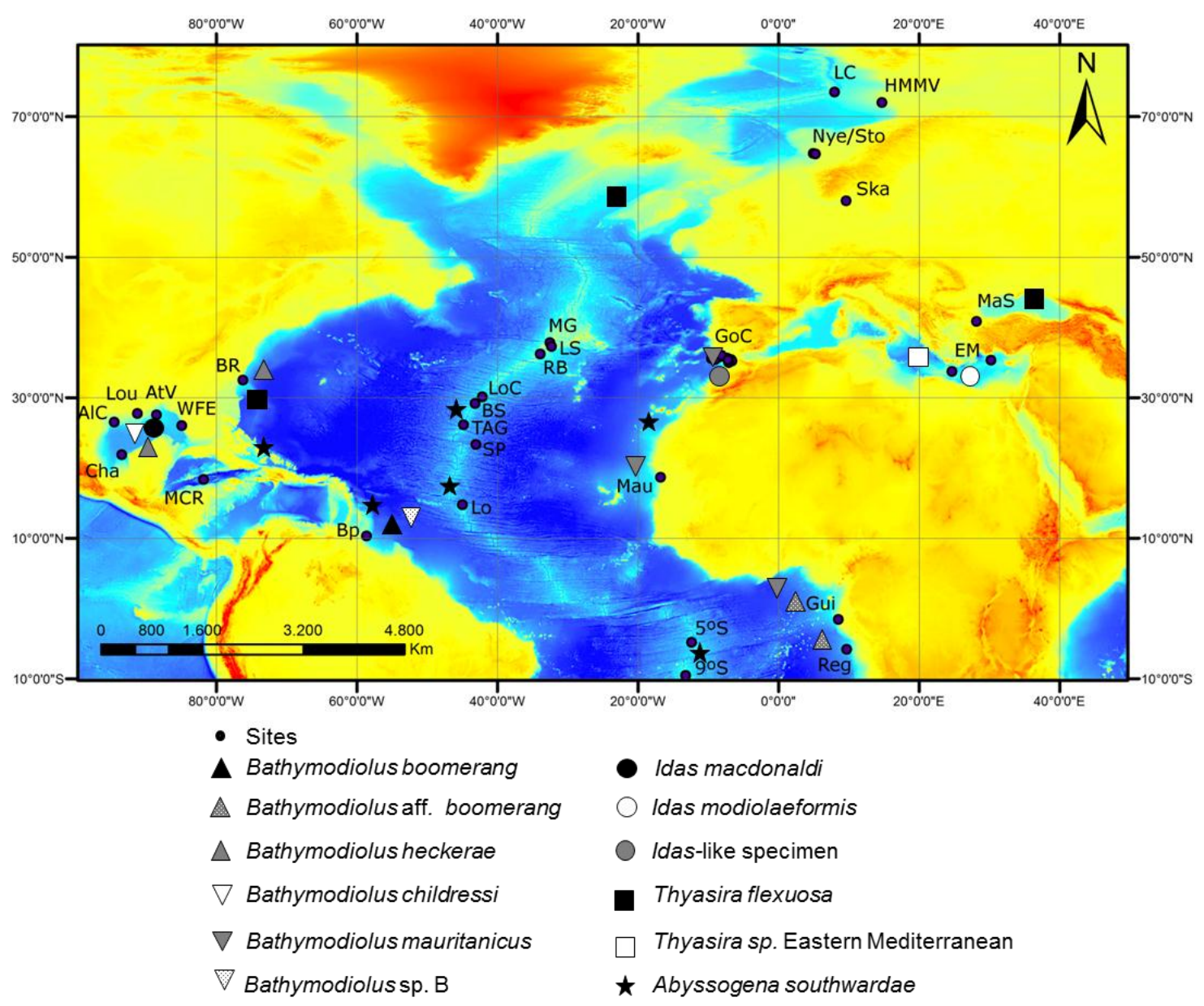

Fig. 1. Map displaying the deep-sea hydrothermal vent and cold seep sites from which chemosymbiotic bivalves were sampled in the North Atlantic and Mediterranean. Western Atlantic (including Gulf of Mexico) from north to south: Blake Ridge (BR), Louisiana slope (Lou), Atwater Valley (AtV), Alaminos Canyon (AlC), West Florida Escarpment (WFE), Chapopote (Cha), Mid-Cayman Ridge (MCR), Barbados prism (Bp); Mid-Atlantic Ridge (MAR) from north to south: Menez Gwen (MG), Lucky Strike (LS), Rainbow (RB), Lost City (LoC), Broken Spur (BS), Trans-Atlantic Geotraverse (TAG), Snake Pit (SP), Logatchev (Lo), $5^{\circ} \mathrm{S}$ and $9^{\circ} \mathrm{S}$; eastern Atlantic from north to south: Loki's Castle (LC), Haakon Mosby (HMMV), Nyegga/Storegga (Nye/Sto), Skagerrak (Ska), Gulf of Cadiz (GoC), Mauritania basin (Mau), Guiness (Gui) and Regab (Reg) sites at Gulf of Guinea; Mediterranean Sea from west to east: eastern Mediterranean (EM) and Sea of Marmara (MaS). Bivalve species or sister species with a trans-Atlantic distribution are indicated by symbols, a similar shape (for example, circle) indicating same (identical color) or sister (distinct colors) species.

Here we provide an overview of the current knowledge available on chemosymbiotic bivalve species in the region ranging west-to-east from the Gulf of Mexico (GoM) to the Sea of Marmara, and north-to-south from the Arctic to the Gulf of Guinea (GoG, Fig. 1). Characteristics of symbioses are summarized for each of the five bivalve families in which chemosynthetic symbionts are documented (with a note on the recently investigated Nucinellidae), and followed by a synthesis focusing on species from the area. Although some features are shared between families, the degree of dependency between host and symbionts or the mode of symbiont acquisition and transmission may vary. The final part of this review attempts to compare and contrast features in the different families to uncover general trends in bivalve chemosynthetic symbioses. Several authors have formerly alluded to unexpected trans-Atlantic distributions of certain chemosymbiotic bivalve species or sister-species along the Atlantic equatorial belt (AEB, Fig. 1), and thus a specific goal was to evaluate whether this hypothesis also holds true for their associated symbionts (Cordes et al., 2007; Génio et al., 2008; Olu et al., 2010; Olu-LeRoy et al., 2007b). A check list of species in which symbiosis has been documented is also provided (Table 1). 
Table 1. Summary of chemosymbiotic bivalve species for which data are available regarding symbiosis in the Atlantic, Gulf of Mexico, and Mediterranean Sea. Numbers in parentheses indicate the number of species for which symbiosis is documented using electron microscopy and molecular data, possibly including in situ hybridization of symbionts (bold). Synonymized taxa, according to the World Register of Marine Species (WORMS, www.marinespecies.org), are included as many former names were in use when symbioses were initially documented, and thus appear in the tree (Fig. 2). Species within genus "Pliocardia" were recently ascribed to undetermined genus (Audzijonyte et al., 2012). Symbiont (Sym.) types: sulfide (S)-oxidizer, methane (M)-oxidizer, (My) methylotrophs, Bacteroidetes (B), Cycloclasticus(Cy)-related and (G) for Gammaproteobacteria unrelated to other documented symbiont groups. Location (Loc.) corresponds to north (N), south (S), east (E), west (W) Atlantic (A), and Mediterranean (Med). Type (Ty.) of chemosynthesis-based ecosystem is mentioned for deep-sea species, (CS) cold seeps, (HV) hydrothermal vents, and (OF) organic falls. A non-exhaustive list of sampling sites is provided for vent and seep species (vent and seep sites illustrated in Fig. 1). Reproduction (Rep.), when documented, is either gonochoric $(\mathrm{G})$ or hermaphrodite $(\mathrm{H})(-\mathrm{p}$ then means protandric), and can be seasonal (-s). For references, see text.

\begin{tabular}{|c|c|c|c|c|c|c|}
\hline $\begin{array}{l}\text { Accepted } \\
\text { species name }\end{array}$ & $\begin{array}{l}\text { Synonymized } \\
\text { taxa }\end{array}$ & Sym. & Loc. & Ty. & $\begin{array}{l}\text { Sampling sites } \\
\text { (vent/seep species) }\end{array}$ & Rep. \\
\hline \multicolumn{7}{|l|}{ SOLEMYIDAE (6/11) } \\
\hline Acharax sp. & & $\mathrm{S}$ & EA & $\mathrm{CS}$ & Gulf of Guinea (Guiness site) & \\
\hline Acharax gadirae & & $\mathrm{S}$ & WA & CS & Gulf of Cadiz & \\
\hline Solemya elarraichensis & & $\mathrm{S}$ & NEA & CS & Gulf of Cadiz & \\
\hline Solemya velum & & $\mathrm{S}$ & NWA & & & G-s \\
\hline Solemya borealis & & $\mathrm{S}$ & WA & & & \\
\hline Solemya occidentalis & & $\mathrm{S}$ & WA & & & \\
\hline \multicolumn{7}{|l|}{ LUCINIDAE (16/85) } \\
\hline Anodontia (Loripinus) fragilis & & $\mathrm{S}$ & EA, Med & & & \\
\hline Anodontia alba & & $\mathrm{S}$ & WA & & & \\
\hline Codakia orbicularis & & $\mathrm{S}$ & NWA & & & G-s \\
\hline Ctena orbiculata & Codakia orbiculata & $\mathrm{S}$ & WA & & & G \\
\hline Divalinga quadrisulcata & Divaricella quadrisulcata & $\mathrm{S}$ & WA & & & \\
\hline Loripes lucinalis & Loripes lacteus & $\mathrm{S}$ & A & & & G-s \\
\hline Lucina pensylvanica & Linga pensylvanica & $\mathrm{S}$ & WA & & & $\mathrm{G}$ \\
\hline Lucinisca nassula & Lucina nassula & $\mathrm{S}$ & WA & & & \\
\hline Lucinoma asapheus & & $\mathrm{S}$ & NEA & CS & Gulf of Cadiz & \\
\hline Lucinoma borealis & & $\mathrm{S}$ & NEA & & & \\
\hline Lucinoma kazani & & $\mathrm{S}$ & Med & CS & Mediterranean, Sea of Marmara & \\
\hline Myrtea spinifera & & $\mathrm{S}$ & NEA, Med & CS & Mediterranean, Sea of Marmara & \\
\hline Parvilucina costata & Codakia costata & $\mathrm{S}$ & WA & & & \\
\hline Parvilucina pectinella & Codakia pectinella & $\mathrm{S}$ & WA & & & \\
\hline Phacoides pectinata & Lucina pectinata & $\mathrm{S}$ & WA & & & H-p-s \\
\hline Stewartia floridana & Lucina floridana & $\mathrm{S}$ & WA & & & \\
\hline \multicolumn{7}{|l|}{ THYASIRIDAE (9/59) } \\
\hline Axinulus croulinensis & & $\mathrm{S}$ & EA; WA & & & G \\
\hline Thyasira equalis & Parathyasira equalis & $\mathrm{S}$ & EA; WA & & Skagerrak & G \\
\hline Thyasira flexuosa & & $\mathrm{S}$ & EA; WA, Med & & & \\
\hline Thyasira gouldi & & $\mathrm{S}$ & EA;WA & & & \\
\hline Thyasira sarsi & & $\mathrm{S}$ & EA; WA & & Skagerrak & \\
\hline Thyasira trisinuata & & $\mathrm{S}$ & WA & & & $\mathrm{G}$ \\
\hline Thyasira vulcolutre & & $\mathrm{S}$ & NEA & $\mathrm{CS}$ & Gulf of Cadiz & \\
\hline Thyasira n. sp. Regab & & $\mathrm{S}$ & EA & $\mathrm{CS}$ & Gulf of Guinea (Regab site) & \\
\hline Thyasira sp. Guiness & & $\mathrm{S}$ & EA & $\mathrm{CS}$ & Gulf of Guinea (Guiness site) & G \\
\hline \multicolumn{7}{|c|}{ MYTILIDAE, clade Bathymodiolinae (11/18) } \\
\hline Bathymodiolus azoricus & & M, S & A & $\mathrm{HV}$ & Mid-Atlantic Ridge & G-s \\
\hline Bathymodiolus boomerang & & $\mathrm{M}, \mathrm{S}$ & A & CS & $\begin{array}{l}\text { Barbados prism, relative in the } \\
\text { Gulf of Guinea }\end{array}$ & \\
\hline Bathymodiolus brooksi & & M, S & WA & CS & Gulf of Mexico & \\
\hline Bathymodiolus childressi & & M & WA & $\mathrm{CS}$ & $\begin{array}{l}\text { Gulf of Mexico, relative in the } \\
\text { Barbados prism }\end{array}$ & G-s \\
\hline Bathymodiolus heckerae & & M, 2S, My, Cy & WA & $\mathrm{CS}$ & Gulf of Mexico, Blake Ridge & \\
\hline Bathymodiolus mauritanicus & & M, S & NEA & CS & $\begin{array}{l}\text { Gulf of Cadiz. Mauritania, } \\
\text { Nigerian margin }\end{array}$ & G-s \\
\hline Bathymodiolus puteoserpentis & & $\mathrm{M}, \mathrm{S}$ & A & $\mathrm{HV}$ & Mid-Atlantic Ridge & G-s \\
\hline Idas macdonaldi & & $\mathrm{S}$ & WA & $\mathrm{CS}, \mathrm{OF}$ & Gulf of Mexico & \\
\hline Idas modiolaeformis & & M, 2S, My, G, B & NEA & $\mathrm{CS}, \mathrm{OF}$ & Mediterranean, Gulf of Cadiz & H-p \\
\hline Idas simpsoni & & $\mathrm{S}$ & NEA & $\mathrm{OF}$ & & \\
\hline Idas sp. Marmara & & $\mathrm{S}$ & Mar & CS & Sea of Marmara & \\
\hline
\end{tabular}


Table 1. Continued.

\begin{tabular}{|c|c|c|c|c|c|c|}
\hline $\begin{array}{l}\text { Accepted } \\
\text { species name }\end{array}$ & $\begin{array}{l}\text { Synonymized } \\
\text { taxa }\end{array}$ & Sym. & Loc. & Ty. & $\begin{array}{l}\text { Sampling sites } \\
\text { (vent/seep species) }\end{array}$ & Rep. \\
\hline \multicolumn{7}{|l|}{ VESICOMYIDAE (11/29) } \\
\hline Abyssogena southwardae & & $\mathrm{S}$ & A & $\mathrm{HV}, \mathrm{CS}$ & $\begin{array}{l}\text { Barbados prism, Florida, Mid- } \\
\text { Atlantic Ridge, Canary Islands }\end{array}$ & \\
\hline Calyptogena valdiviae & Vesicomya valdiviae; V. longa & $\mathrm{S}$ & EA & $\mathrm{CS}$ & Gulf of Guinea & G \\
\hline Christineconcha regab & Calyptogena regab & $\mathrm{S}$ & EA & $\mathrm{CS}$ & Gulf of Guinea, Bay of Biscay & \\
\hline Elenaconcha guiness & & $\mathrm{S}$ & EA & $\mathrm{CS}$ & Gulf of Guinea & \\
\hline Isorropodon bigoti & & $\mathrm{S}$ & EA & $\mathrm{CS}$ & Gulf of Guinea & G \\
\hline Isorropodon megadesmus & & $\mathrm{S}$ & NEA & $\mathrm{CS}$ & Gulf of Cadiz & \\
\hline Isorropodon perplexum & & $\mathrm{S}$ & Med & $\mathrm{CS}$ & Mediterranean, Sea of Marmara & \\
\hline Laubiericoncha chuni & Vesicomya chuni & $\mathrm{S}$ & EA & $\mathrm{CS}$ & Gulf of Guinea & \\
\hline Laubiericoncha myriamae & & $\mathrm{S}$ & NA & $\mathrm{CS}$ & Barbados prism & \\
\hline "Pliocardia" cordata & Vesicomya cordata & $\mathrm{S}$ & WA & $\mathrm{CS}$ & Gulf of Mexico & \\
\hline "Pliocardia" ponderosa & Calyptogena ponderosa & $\mathrm{S}$ & WA & CS & Gulf of Mexico; Colombia & \\
\hline
\end{tabular}

\section{Chemosymbiotic bivalves and their symbioses}

\subsection{Mytilidae}

One clade within the family Mytilidae has successfully colonized the deep sea, in habitats in which methane, reduced sulfur species or hydrogen is available as energy sources. These habitats include cold seeps, hydrothermal vents, or organic falls such as cetacean carcasses or sunken wood. This deep-sea mussel clade is often referred to as the subfamily Bathymodiolinae typified by the genus Bathymodiolus Kenk and Wilson (1985), a large vent and seep mussel genus (Kenk and Wilson, 1985). In reality, several genera of smaller mussels such as Idas, Adipicola (formerly Myrina), Benthomodiolus, and Tати, some of which were described long before the discovery of Bathymodiolus and chemosynthetic ecosystems, also form part of the clade. This is despite the fact that they have been historically included in the subfamily Modiolinae, along with Modiolus modiolus, a species often used as an out-group in deep-sea mussel phylogenies (Distel et al., 2000; Jones et al., 2006; Lorion et al., 2010; Samadi et al., 2007). Notably, deep-sea mytilids are almost absent from the background fauna, except for few small species within genus Dacrydium, a group in which symbiosis has not been investigated (Duperron, 2010; Salas and Gofas, 1997). Contrary to most other chemosymbiotic bivalves discussed in this paper, mussels are epibenthic, and occur attached to hard substrates including carbonates, basalts, tubes of large tube worms (Annelida: Siboglinidae) or shells of other specimens, via a byssus. Exceptions include Bathymodiolus boomerang, which lives partly buried in the sediment at the Barbados seeps (Cosel and Olu, 1998; Duperron, 2010). These mussels occur mostly in areas of diffuse fluid flow, and avoid the hottest or most anoxic niches (Fisher et al., 1988, Desbruyères et al, 2000). The genera themselves (e.g., Bathymodiolus, Idas, or Adipicola) remain poorly defined based on morphological characteristics, and are clearly non-monophyletic (Carney et al., 2006; Jones et al., 2006;
Lorion et al., 2010). Cosel (2002) re-evaluated most of the species of Bathymodiolus, based upon morphological characteristics of the shells and soft parts, and suggested a division into four groups (Bathymodiolus thermophilus group, $B$. brevior group, $B$. heckerae/boomerang group and the $B$. childressi group) (Cosel, 2002). Keeping in mind the above limitations, several common features are conserved within the group, such as the overall modioliform shape, the gross anatomy, the presence of often reduced digestive tract and labial palps, and of hypertrophied gills in most species (reviewed in Duperron, 2010). Nevertheless the most striking shared feature is the presence of bacterial symbionts associated with epithelial cells in the lateral zone of gill filaments in all species. A possible exception is Idas argenteus previously collected from woods in the North Atlantic, which feed on larvae of wood-boring bivalves as evidenced by the presence of remnants in their gut (Ockelmann and Dinesen, 2011). However, I. argenteus may not belong to the Bathymodiolinae.

Mussel species investigated to date associate with between one and six distinct types of bacterial symbionts. Each type displays a distinct $16 \mathrm{~S}$ rRNA-encoding gene sequence, which is used as a barcode for identifying and characterizing phylogenetic relationships in bacteria (Fig. 2). Most frequently they correspond to sulfur-oxidizing (thiotrophic) or, in some species, methane-oxidizing (methanotrophic) Gammaproteobacteria (Cavanaugh, 1983; Cavanaugh et al., 1987; Felbeck et al., 1981; Rau and Hedges, 1979). Dual symbioses involving both sulfur- and methane-oxidizing bacteria simultaneously have been reported (Distel et al., 1995; Fiala-Médioni et al., 2002; Fisher, 1993; Olu et al., 1996). More recently, other phylotypes were documented corresponding to methylotrophs, belonging to a clade named Gammaproteobacteria G, to hydrocarbon-degrading bacteria of the genus Cycloclasticus, and to Bacteroidetes (Duperron et al., 2007b, 2008a, Raggi et al., 2012). In the Bathymodiolinae, sulfur-oxidizing symbionts are small bacteria that occur either inside gill epithelial cells, within vacuoles, 
or outside the cells, within a layer of microvilli, depending on the host species (Duperron et al., 2008b, 2009; Gros and Gaill, 2007; Lorion et al., 2009; Miyazaki et al., 2010). They oxidize reduced sulfur compounds (sulfide, thiosulfate) and use the energy for carbon fixation via the Calvin cycle, using a Type I RubisCO (Fisher et al., 1988; Nelson et al., 1995; Pimenov et al., 2002). Recently, mussel-associated thiotrophs were shown to use hydrogen as an alternative energy source not only at the hydrogen-enriched ultramafic vents of Logatchev, but also at the hydrogen-poor southern $\operatorname{MAR}\left(5^{\circ} \mathrm{S}\right.$ and $\left.9^{\circ} \mathrm{S}\right)$, based on the presence of hydrogenaseencoding genes. Pacific-Antarctic Ridge mussel symbionts also displayed the gene, but the gene was not amplified from Gulf of Mexico seep mytilids, suggesting this ability is not always present (Petersen et al., 2011). The methaneoxidizers are related to free-living Type I methanotrophs; they are intracellular and larger than thiotrophs, and display Type I-typical stacked internal membranes within their cytoplasm (Cavanaugh et al., 1987). They possess methane monooxygenase, an enzyme found only in methanotrophs, and use methane as both a carbon and energy source (Cary et al., 1988; Childress et al., 1986; Duperron et al., 2007b; Pernthaler and Amann, 2004). Evidence on the occurrence of a RubisCO gene, and thus possibly an alternative autotrophic pathway of carbon assimilation, was presented in a species from the Pacific Ocean (Elsaied et al., 2006). Recently, genes enabling the use of aromatic compounds were identified in a symbiotic lineage related to Cycloclasticus, present in the gills of Bathymodiolus heckerae specimens from an asphalt seep in the Gulf of Mexico (Raggi et al., 2012). The metabolism of other symbionts (methylotrophs, Gammaproteobacteria $\mathrm{G}$ and Bacteroidetes) has not yet been investigated, and hypotheses are based on weak phylogenetic inferences (Duperron et al., 2007b, 2008a). For example methylotrophs in $B$. heckerae were hypothesized to take up methanol from nearby methane-oxidizers.

Within the area considered in the present review, large Bathymodiolus are reported from cold seeps in the Gulf of Mexico (B. childressi, B. brooksi, B. heckerae), the Barbados accretionary prism (B. boomerang, $B$. sp. B related to $B$. childressi), the Blake Ridge diapir (B. heckerae), the MidAtlantic Ridge hydrothermal vents (B. azoricus, B. puteoserpentis, and relatives of uncertain species status at sites $5^{\circ} \mathrm{S}$ and $9^{\circ} \mathrm{S}$, displaying distinct $\mathrm{COI}$ haplotypes closely related to $B$. azoricus). Bathymodiolus are also reported from seeps off Mauritania and the Gulf of Cadiz (B. mauritanicus), off Nigeria (B. aff. mauritanicus and B. aff. boomerang, with no detail regarding symbiosis), and at deep seeps in the Gulf of Guinea (B. aff. boomerang, Fig. 1). They are not yet documented from the Mediterranean. Interestingly two groups of closely related species, $B$. boomerang/B. heckerae and B. mauritanicus/B. sp. B/ B. childressi, display an amphiAtlantic distribution, which led authors to postulate a dispersal route following the Atlantic equatorial belt (the AEB hypothesis discussed in Cordes et al., 2007; Génio et al.,
2008; Olu et al., 2010; Olu-LeRoy et al., 2007b (Fig. 1)). Speciation could also have occurred along this belt. All but B. childressi, which has only methanotrophs, harbor multiple symbionts, with simultaneous occurrence of one sulfurand one methane-oxidizer. $B$. heckerae specimens also have a second distinct sulfur-oxidizer, a methylotroph-related symbiont in the northern GoM, and hydrocarbon-degrading bacteria in the southern GoM (DeChaine et al., 2006; Distel et al., 1995; Duperron et al., 2005, 2007b; Fisher et al., 1993, Raggi et al., 2012) (Fig. 2). In fact, all Bathymodiolus species documented to harbor two or more different symbionts with distinct metabolisms are documented from seeps and vents in the Atlantic and Gulf of Mexico. Multiple symbioses are not yet documented in Bathymodiolus species from other oceans. Multiple symbiosis is a common feature of mussels within a clade that includes $B$. azoricus, the two mytilids from $5^{\circ} \mathrm{S}$ and $9^{\circ} \mathrm{S}$ MAR, B. puteoserpentis, B. heckerae, B. boomerang and $B$. aff. boomerang, a group that diverged around $6.2 \mathrm{Mya}$ (Miyazaki et al., 2010). This could be a phylogenetic trend, but multiple symbioses also occur in $B$. brooksi, which is only distantly related to this group (Jones et al., 2006; Lorion et al., 2010), and in B. mauritanicus whereas the sister species $B$. childressi harbors only methanotrophs (Rodrigues et al., 2013). Symbioses involving two or more types of bacterial metabolisms were hypothesized to confer flexibility to their host, by allowing fine-tuning of the symbiont population for optimized resource use in habitats with high spatial and temporal variability (Distel et al., 1995). This hypothesis was confirmed by several studies on B. azoricus and B. puteoserpentis from MAR vents. Symbiont densities based on transmission electron microscopy (TEM) counts were shown to differ between sites in B. azoricus (FialaMédioni et al., 2002). More recently, using more quantitative approaches with statistical support, differences in the absolute and relative abundance of sulfur- and methane-oxidizers were demonstrated (Halary et al., 2008). Relative abundances of symbionts qualitatively mirrored the respective amount of energy available from the substrates used by each symbiont in local mussel habitats on MAR vents (Le Bris and Duperron, 2010). Experiments confirmed that a short sulfur or methane pulse stimulates growth of thiotrophic or methanotrophic symbionts, respectively (Halary et al., 2008; Riou et al., 2008), and also showed that symbiont densities vary over time. At cold seeps in the northern Gulf of Mexico, methaneoxidizers dominate the symbiont population, but differences in symbiont abundances were observed between $B$. heckerae and B. brooksi. Specimens of B. brooksi from Alaminos Canyon showed lower symbiont densities compared to those from Atwater Canyon (Duperron et al., 2007b). A variability in relative abundances of symbionts was linked with the characteristics of local habitats for $B$. aff. boomerang at the Regab and DIAPIR sites (Gulf of Guinea). Methanotrophs dominated in the gills of all specimens, with higher relative abundances at a site with direct evidence of high flux (bubbling, high degassing activity), and the highest methane 
concentration in bottom waters (Duperron et al., 2011). Stable isotope signatures correlated with these measurements, suggesting that specimens with more methane-oxidizers derived a substantially higher fraction of their carbon from methane, and a lower fraction of their sulfur from sulfide. This confirms that multiple symbioses are highly adaptable to changing habitats, both in time and space, optimizing the use of resources. In Bathymodiolus, heterotrophy plays a limited role, but a fraction of carbon is derived from particulate and dissolved organic matter at shallower sites, as seen for B. azoricus at the $800 \mathrm{~m}$ deep Menez Gwen site (Riou et al., 2010), or during early life (Martins et al., 2008).

Symbioses in smaller mytilids from the Atlantic, Gulf of Mexico and Mediterranean have been far less documented. Tamu fisheri, which inhabits the base of Lamellibrachia luymesi (Annelida: Siboglinidae) aggregations and beds of B. childressi, and Idas simpsoni from the North Sea both harbor extracellular sulfur-oxidizing bacteria associated with their gill epithelial cells. This observation was based on electron microscopy data, but no molecular characterization is available yet (Southward, 2008). Conversely, the sulfuroxidizing bacteria associated with Idas macdonaldi, occurring at $650 \mathrm{~m}$ on the Louisiana Slope, were characterized by 16S rRNA gene sequencing only (Won et al., 2008). Interestingly, this species has a well-developed digestive system in comparison with others from the group, suggesting mixotrophy (Gustafson et al., 1998). Two Idas species were investigated in more detail, combining molecular and microscopic confirmative approach data. The first is an unnamed species recovered in the Sea of Marmara, tentatively ascribed to the genus Idas and labeled Idas sp. Marmara. The second is Idas modiolaeformis, a species identified in the eastern Mediterranean cold seeps with very close relatives recently sampled and investigated in the northeast Atlantic (Duperron et al., 2008a; Lorion et al., 2012; Ritt et al., 2012; Rodrigues et al., 2013). Despite its apparent morphological resemblance with Idas modiolaeformis, with similar habitat and depth range, Idas sp. Marmara is at best distantly related to other Idas lineages and branches quite far from other Bathymodiolinae based on COI analysis (17\% divergence from any other mussel). Idas sp. Marmara hosts dense populations of sulfuroxidizing bacteria in its gill epithelial cells. Idas modiolaeformis was initially described in the late 19th century, and was re-sampled only recently (Olu-LeRoy et al., 2004). It can harbor 6 distinct bacterial 16S rRNA phylotypes in its gills, including two sulfur- and one methane-oxidizers, one methylotroph, one Bacteroidetes and one belonging to the "Gammaproteobacteria G" clade (Duperron et al., 2008a) (Fig. 2). Depending on sampling years or substrates, either sulfur- or methane-oxidizers dominate in the gills, but their abundance in relation to the local geochemistry was not investigated (Lorion et al., 2012). The species displays protandric hermaphrodism with possible gender transitions during adult life, and symbionts are absent from the gonad tissue, which support environmental acquisition later during devel- opment or after larval settlement. The larval shell (Fig. 3f) suggests planktotrophic larvae with some dispersal capabilities (Gaudron et al., 2012). Idas modiolaeformis is the sister species of Idas macdonaldi known from the Gulf of Mexico and possibly diverged around 1.84 Mya. This amphiAtlantic distribution led to the prediction that populations of mussels branching within the I. modiolaeformis/I. macdonaldi clade should occur at locations in between the eastern Mediterranean and the Gulf of Mexico. Recently, small Idas-like mussels were indeed recovered from the northeast Atlantic on organic substrates at mud volcanoes in the Gulf of Cadiz (Darwin and Meknès MVs) and in the Gorringe Bank (Gettysburg Seamount) (Rodrigues et al., 2013). The studied specimens display COI sequences identical (Gorringe) or almost identical (Meknès, Darwin MVs) to the specimens from the eastern Mediterranean, suggesting they belong to the same species. Possible settlement is also reported on wood block colonization experiments deployed in the western Mediterranean canyons at $500 \mathrm{~m}$ deep (personal observation, N. Le Bris, personal communication, 2012). Interestingly, molecular and microscopic data suggest the absence of methane-oxidizing symbionts. Furthermore, specimens from the Meknès and Gorringe sites do not seem to have sulfur-oxidizers either. Identified bacteria either belong to the "Gammaproteobacteria G" group, present in I. modiolaeformis, or to a clade unrelated to any known symbiont (clone G-4), or to the Bacteroidetes. Overall, symbioses in the I. macdonaldi/I. modiolaeformis clade appear unexpectedly variable. This could be linked with the wide range of habitats colonized, which include alfalfa and wood colonization devices, natural wood falls, carbonates close to reduced sediment, and siboglinid tubes. The plasticity of the I. macdonaldi/I. modiolaeformis clade makes it a very good model to study at which stage of the life cycle (spawned oocytes, veliger stages, post-larvae, aposymbiotic juveniles or adult stages) and how symbionts establish, transmit and evolve over a relatively short evolutionary time scale. Other Idas species have been associated with reduced environments. In the Mediterranean, for example, I. simpsoni and I. cylindricus have been associated with organic falls (Pastorelli et al., 1999; Pelorce and Poutiers 2009). Another unidentified Idas was found on organic cargo in the wrecked ship François Vieljeux (Dando et al., 1992).

Besides documented chemosynthetic gill-associated symbionts, deep-sea mytilids were shown to be affected by several potentially pathogenic micro-organisms, including viruses, prokaryotes, and ciliates (Ward et al., 2004). The most intriguing potential pathogen yet is a lineage of intranuclear Gammaproteobacteria related to various sequences recovered from clone libraries from metazoans (Zielinski et al., 2009). Candidatus "Endonucleobacter bathymodioli" invades and disrupts the nuclei of symbiont-free gill intercalary cells in several Bathymodiolus species. This group is thought to be widespread in deep-sea metazoans, but remains to be confirmed in other chemosymbiotic bivalves. 


\subsection{Vesicomyidae}

The family Vesicomyidae consists of over 100 known species, distributed worldwide at depths from 100 to $9500 \mathrm{~m}$ (Baco et al., 1999; Cosel and Olu, 2009; Krylova and Sahling, 2010). As in other families of chemosymbiotic bivalves, currently applied genera are under intense discussion (Krylova and Sahling, 2010, Audzijonyte et al., 2012). The subfamily Vesicomyinae, genus Vesicomya, consists of smaller species, up to $1 \mathrm{~cm}$ shell length, which inhabit the abyssal plain. In contrast, representatives of the Pliocardiinae can reach up to $30 \mathrm{~cm}$ and colonize a variety of deep-sea reducing habitats including cold seeps, hydrothermal vents, and vertebrate carcasses (Krylova and Sahling, 2010). Most species are infaunal and possess siphons of varying length. They live with their anterior region buried into reducing sediment, although some vent species inhabit the cracks or small crevices on bare basalts. They thus bridge the oxic/anoxic interface (Cavanaugh et al., 2005). This way they can access both oxygen and dissolved carbon, as well as reduced compounds that seep from the subsurface or are concentrated within the underlying sediment layers that they can reach using their vermiform foot (Childress and Mickel, 1982). Characteristic features of the Pliocardiinae are a mediumto-large white shell, reduced labial palps, simple gut (FialaMédioni and Le Pennec, 1987), sub-filamental tissue in the gills (Krylova and Sahling, 2010), large and thick gills, and the presence of very dense intracellular sulfur-oxidizing autotrophic Gammaproteobacteria located within gill epithelial bacteriocytes. Certain species of Vesicomyidae possess hemoglobin molecules capable of transporting hydrogen sulfide via the hemolymph, from the foot to the gill symbionts (Childress et al., 1993). Oxygen is acquired directly by the gill and in some species transported by circulating hemoglobin (Terwilliger et al., 1983). In some species, the gills are also organized in tubes or channels (Le Pennec et al., 1988). Several species can co-occur at a given seep or vent site, sometimes within a single clam aggregate, as observed in the Gulf of Guinea with Christineconcha regab and Laubiericoncha chuni (Decker et al., 2012; Krylova and Cosel, 2011). Physiological differences between some species could account for slight ecological niche differentiation and prevent competition (Goffredi and Barry, 2002; Decker at al., 2013).

Symbionts associated with the Vesicomyidae are related to the sulfur-oxidizing symbionts of the Mytilidae and sponges, as well as to various free-living bacteria (Fig. 2). They use reduced sulfur as an energy source and fix carbon through the Calvin cycle, but contrary to mussel symbionts, they employ a Type II instead of Type I RubisCO (Robinson and Cavanaugh, 1995). Vesicomyid symbionts form a tight clade that displays a high homogeneity among 16S rRNA sequences; the most dissimilar sequences differ by only $8.1 \%$ (Rodrigues et al., 2012), despite the fact that the family is quite ancient (estimates varying from 100 Mya based on the fossil record to 22-44 Mya with molecular estimated; Little and Vrijenhoek, 2003). Symbionts are transmitted directly from mother to offspring as evidenced by polymerase chain reaction (PCR) and in situ hybridization (ISH) tests using symbiont-specific primers and probes (Endow and Ohta, 1990; Krueger et al., 1996b). Host and symbiont phylogenies can be superimposed, suggesting rather strict co-speciation (Peek et al., 1998a, b). However, a limited amount of lateral transfer does exist and may permit gene exchanges between symbiont lineages (Stewart et al., 2008, 2009b; Decker et al., 2013). To date, the Vesicomyidae are the only deepsea chemosymbiotic metazoans for which symbiont genomes are fully sequenced - namely Candidatus "Vesicomyosocius okutanii" and Candidatus "Ruthia magnifica", in two species from the Pacific (Kuwahara et al., 2007; Newton et al., 2007). Genome sequencing indicates the loss of several genes and strong genome reduction compared to free-living relatives. This trait, shared with many symbionts in insect, is characteristic of maternally inherited bacterial symbionts lacking a free-living stage, and is thus congruent with previous findings (Gil et al., 2004; Wernegreen et al., 2003). In Cand. "Vesicomyosocius okutanii", the loss of the fts $Z$ gene involved in bacterial division suggests, for example, strong host control over the symbiont cycle (Kuwahara et al., 2007). Significant variations also exist among the metabolisms of the closely related symbionts. Cand. Ruthia magnifica does not harbor the membrane-bound nitrate reductase present in Cand. Vesicomyosocius okutanii, suggesting that only the latter is able to respire nitrate (Kleiner et al., 2012). Another consequence of genome alteration is that the existence of active free-living forms of vesicomyid symbionts is questionable. Although the issue is not settled, no environmental sequence from any active bacterium yet clusters inside the group. The only exception is the symbiont sequence from a thyasirid, Thyasira vulcolutre, which was recently shown to cluster within this group, suggesting a host shift (Fig. 2) (Rodrigues and Duperron, 2011).

Despite the fact that approximately 29 Vesicomyidae species are documented in the Atlantic and Mediterranean Sea, symbiosis has been investigated in only 11 species (Table 1). Among these is Abyssogena southwardae, which occurs at seeps on the west coast of Florida and at the Barbados prism, with large populations on very deep mud volcanoes. At vent sites Logatchev $5^{\circ} \mathrm{S}$ and $9^{\circ} \mathrm{S}$, old shells of this species were found in dredgings from a seamount near the Canary Islands, even though conditions may never have been optimal to support a stable population; the small field observed in 1997 had disappeared in 2007 (Gebruk et al., 2010). Interestingly, they could represent populations of an amphi-Atlantic species, and MAR vents and Florida species also have very closely related symbionts (van der Heijden et al., 2012; Krylova et al., 2010). The genus Laubiericoncha could be amphi-Atlantic, with Laubiericoncha myriamae from Barbados (Jollivet et al., 1990; Cosel and Olu, 2008) and L. chuni in the Gulf of Guinea. Recent molecular data 
suggest that species should be included in distinct genera (Decker et al., 2012). Although ultrastructural evidence exists for sulfur-oxidizing symbiosis in L. myriamae, no molecular data have been released regarding symbionts (Olu et al., 1996). In both A. southwardae and L. myriamae, genetic data regarding symbiosis are not available for specimens from the eastern Atlantic. Another species, Pliocardia atalantae (formerly Isorropodon atalantae), has been documented from the Gulf of Guinea to the Mid-Atlantic Ridge, but no data are available regarding symbiosis.

In the Gulf of Mexico, vesicomyids are represented by Pliocardia ponderosa (formerly Calyptogena ponderosa) and Pliocardia cordata (formerly Vesicomya cordata) (Table 1). They both display closely related sulfur-oxidizing symbionts (Fig. 2) (Brooks et al., 1987; Distel et al., 1994; Stewart et al., 2009b) and an abundance of hemoglobin (Scott and Fisher, 1995). Species from seeps in the Gulf of Guinea have recently received attention. These include Elenaconcha guiness, Isorropodon bigoti and Calyptogena valdiviae. E. guiness was found to display a very typical vesicomyid symbiosis, as documented in many other species around the world (Duperron et al., 2012). This species displays a single symbiont $16 \mathrm{~S}$ rRNA phylotype, with high similarity to other vesicomyid-associated symbiont sequences available in Genbank, and sulfur metabolism is supported by the presence of the gene encoding APS (adenylyl-sulfate) reductase and by carbon stable isotope values in the range of those reported for seep vesicomyids (Olu et al., 2009). With regards to connectivity, small clams of the genus Isorropodon yielded interesting findings. Specimens of the three species I. perplexum, I. megadesmus and I. bigoti, collected respectively in the eastern Mediterranean, Gulf of Cadiz and Gulf of Guinea, are closely related, forming a distinct clade, based on COI phylogeny (Cosel and Salas, 2001; Rodrigues et al., 2012). Their symbionts also appear as close relatives (Fig. 2), and the association is very similar to that documented in larger clams. The genus Isorropodon consists of various species colonizing a wide range of depths (150-6800 m), and could represent a suitable case study into the barriers influencing the biogeography and evolution of vesicomyid symbioses, as demonstrated by the recent discovery of I. perplexum in the Sea of Marmara (Ritt et al., 2012). Finding closely related symbionts in closely related species is somewhat expected, although instances of non-parental acquisition are reported (Stewart et al., 2008, 2009b; Decker et al., 2013). The homogeneity of symbiont populations within a single species was also questioned recently by the finding of distinct bacterial 16S rRNA lineages in distinct specimens of Calyptogena valdiviae (Fig. 2). Overall, new data about symbioses in the Atlantic Vesicomyidae further support the existence of a certain level of symbiont heterogeneity within species, and of environmental acquisition of non-parental symbiont strains in co-occurring host species, which can potentially lead to symbiont co-occurrence, displacement, or genetic recombination among symbionts. These phenomena might be of great significance for the evolution of vesicomyid symbioses.

\subsection{Solemyidae}

All documented Solemyidae live in obligate symbiosis with sulfur-oxidizing Gammaproteobacteria. They make U- or Yshaped burrows that allow access to both the bottom seawater, rich in oxygen, and sediment pore-waters that contain reduced sulfur (Fisher, 1990; Stewart and Cavanaugh, 2006). Due to their infaunal lifestyle, deep-sea Solemyidae are rarely sampled in great numbers, which limits the possibility to investigate them in detail. Most data were obtained from coastal species. Although a weak suspensionfeeding capability is retained, dependency upon symbiotic nutrition is maximal, as shown by the drastic reduction (Solemya velum), or even absence (Solemya reidi) of the digestive system and reduction in labial palps. Authors estimated that more than $97 \%$ of the carbon is derived from symbionts (Conway et al., 1989; Krueger et al., 1992). Protobranch gills account for more than $35 \%$ of total weight, with a greater surface area to volume ratio than those documented for other bivalves (Scott, 2005). Symbionts are located inside bacteriocytes of the gill epithelium, which alternate with symbiontfree intercalary cells. The symbiont cycle may be complex as bacterial shape is variable from coccoid- to rod-shaped, and dividing stages are rarely seen, suggesting strong host control. Carbon is fixed via the Calvin cycle (Cavanaugh, 1983; Cavanaugh et al., 1988), using energy derived from the oxidation of reduced sulfur, most likely through the APS pathway for which they possess enzymes (Kleiner et al., 2012; Stewart and Cavanaugh, 2006). Ammonia is the nitrogen source assimilated via a host-encoded glutamine synthetase (Lee et al., 1999). Vertical transmission of the symbionts is documented in the genus Solemya based on amplification of symbiont DNA from ovaria, eggs and larvae, although confirmation with in situ hybridizations was not obtained from oocytes and eggs (Cary, 1994; Krueger et al., 1996b). In contrast to the Vesicomyidae, host-symbiont co-speciation is not observed.

Shallow water Atlantic species for which information is available regarding symbiosis include Solemya velum, the model species for the group, found in coastal sediments from Florida to Canada (Nova Scotia) with densities reaching 253 individuals per square meter in eelgrass beds on the coast of Massachusetts (Eisen et al., 1992; Krueger and Cavanaugh, 1997; Stewart and Cavanaugh, 2006). Molecular and ultrastructural information is also available from $S$. occidentalis, a small tropical Atlantic species, $1-3 \mathrm{~mm}$ in length (Conway et al., 1992; Krueger et al., 1996a). Their symbionts belong to the Gammaproteobacteria (Fig. 2). In S. velum, four populations on the New England coast of the USA were shown to harbor distinct symbiont genotypes despite host populations being connected, suggesting decoupling between host and symbiont history (Stewart et 
al., 2009a). This could either be due to the limited resolution of the host marker gene, or a consequence of the lateral acquisition of locally adapted bacteria. Enzymatic and ultrastructural data also exist for $S$. borealis, another small species (Conway et al., 1992). Several species have been documented at deeper depths in the area. In the Mediterranean, a single specimen of an undetermined Solemya is for example the only living Solemyidae species reported in the deep Mediterranean (Rodrigues et al., 2011). It was recovered from a soft sediment core close to a cold seep area of the Nile deep sea fan, at a depth of $1697 \mathrm{~m}$. Unfortunately, no data are available regarding symbiosis, despite attempts to amplify symbiont genes. Acharax gadirae and Solemya (Petrasma) elarraichensis have been documented from deep (Yuma, Ginsburg, Jesus Baraza, Captain Arutyunov, Carlos Ribeiro, Porta MVs, 960-3902 m depth) and shallower MVs (Mercator, Meknès, Gemini, Kidd, Yuma, Ginsburg, Darwin, 358-1105 m depth) respectively in the Gulf of Cadiz (Oliver et al., 2011). Another member of the genus Acharax, not yet assigned to a species, was collected at the Guiness site $(580 \mathrm{~m}$ depth) in the Gulf of Guinea (Duperron et al., 2012). Sequences from symbionts of the two Acharax species (GoC and GoG) are almost identical to sequences of several Acharax from the Oregon, Pakistan and Indonesia margins at depths from 780 to $2940 \mathrm{~m}$ (Imhoff et al., 2003). S. elarraichensis symbiont sequences are, on the other hand, closely related to those of the shallow Solemya velum (Eisen et al., 1992; Rodrigues et al., 2010). Acharax shells, but no living specimens, are documented from various locations including the Norway plateau or in the Barbados seeps (Ivanov et al., 2010; Olu et al., 1996). In addition several other species occur in the area, though no information is available regarding their symbioses (Table 1).

Overall, Acharax-associated symbionts form a very tight cluster despite the geographical distance between collection sites. Meanwhile, Solemya symbionts are spread over at least three distinct clades of Gammaproteobacteria, related to $\mathrm{Lu}$ cinidae and Thyasiridae symbionts (Fig. 2). This distinct clustering could reveal significant differences in the symbioses between the different host genera, and even among species within genus Solemya. For example, carbon fixation in symbionts of Solemya velum is carried out by a Type IA RubisCO, while a Type II RubisCO is present in Acharax sp. Guiness (Duperron et al., 2012; Robinson and Cavanaugh, 1995; Schwedock et al., 2004). Other differences could exist besides the type of RubisCO.

Additional 16S rRNA sequences were recovered besides that of gammaproteobacterial symbionts in Solemya elarraichensis and Acharax gadirae branching within the Epsilonproteobacteria, Betaproteobacteria, Chlamydiae, Firmicutes, and Actinobacteria. Their status as symbionts or pathogens was not resolved, but at least some might have been contaminants. In the Sea of Oman, a family related to Solemyidae, the Nucinellidae, was recently shown to display chemosynthetic sulfur-oxidizing bacteria in their gills based on detailed electron microscopy approaches, but without supporting molecular data (Oliver and Taylor, 2012).

\subsection{Thyasiridae}

Around 100 Thyasiridae species are described worldwide (59 in the area reviewed herein). They occupy various habitats from intertidal to hadal waters, including the deepest reported chemosymbiotic species, Maorithyas hadalis (Fujiwara et al., 2001). Thyasiridae burrow into suboxic to anoxic sediment, in particular in habitats rich in hydrocarbons or fluids (cold seeps, hydrothermal vents) and in oxygen minimum zones. They also occur in organic-enriched habitats such as sunflower seeds in a wrecked ship off Vigo (Spinaxinus sentosus; Oliver and Holmes, 2006), colonizing artificial wood substrates in the eastern Mediterranean close to seeps (Thyasira sp.; Gaudron et al., 2010), and in canyons under reducing and organic-enriched conditions (Cunha et al., 2011). As in the Vesicomyidae and Bathymodiolinae, genera are poorly defined, leading to frequent misidentifications (Taylor et al., 2007). Contrary to other bivalve groups discussed here, not all members of the Thyasiridae harbor bacterial symbionts. In fact, several degrees of association, ranging from the absence of symbionts to the occurrence of very dense bacterial populations in the lateral zone of gill filaments, are documented (Dufour, 2005). This illustrates differing degrees of dependence upon symbiont-based nutrition (Dando and Spiro, 1993), and suggests that symbioses appeared several times during the evolution of the family. Species with symbionts harbor bacteria in large cells located in the gill epithelium. The bacteria are tightly packed into a large vacuole that is devoid of host cell cytoplasm (Fig. 3a) and separated from the outside by a net-like structure that may consist of modified microvilli (Dufour, 2005). These species burrow deeper than non-symbiotic species and use their super-extensile foot to mine for sulfide-rich pockets in the sediment, creating a network of tunnels (Dufour and Felbeck, 2003). Some species such as Thyasira flexuosa and $T$. gouldi lack siphons and maintain communication with the surface seawater by a long tube made of mucus rings created by the foot (Blacknell, 1973). Symbiont chemoautotrophy is supported by the occurrence of APS reductase-encoding genes in symbionts of some species (Rodrigues and Duperron, 2011), and by the carbon stable isotope signatures of animal tissue that are in the range of values measured in chemosymbiotic metazoans harboring sulfur-oxidizing symbionts. Variability in symbiont abundances and the host nutritional strategy depends upon environmental conditions (presence of sulfide and particles), as shown in Thyasira flexuosa, T. sarsi and Parathyasira equalis, confirming their ability to withstand fluctuating environments (Dando and Spiro, 1993; Dufour and Felbeck, 2006).

Symbiosis has been investigated in 9 identified species from coastal and deep sediment, including cold seeps, but molecular data on symbionts remain very scarce (Table 1 ). 
In addition, two unidentified species have been reported by Southward (1986) as having symbiotic associations, each with two distinct bacterial morphotypes, none containing sulfur vesicles. In most investigated species, only the ultrastructure was characterized. Thyasira (Parathyasira) equalis (Barents Sea) and Axinulus croulinensis (North Sea) harbor moderate amounts of extracellular symbionts, while T. trisinuata (Florida), T. sarsi (White Sea, North Sea), T. flexuosa (North Sea), and T. gouldi (Arctic region) harbor dense bacterial populations in their gills (Dufour, 2005). Available 16S rRNA sequences all belong to the Gammaproteobacteria and are related to free-living bacteria and sulfur-oxidizing symbionts of several metazoan groups (Fig. 2). In the area considered herein, these include T. flexuosa from Plymouth Sound (15 m depth), Thyasira aff. flexuosa from the Nile deep-sea fan cold seeps, Thyasira vulcolutre from the Carlos Ribeiro (2200 m depth) and Sagres (1562 m depth) MVs in the Gulf of Cadiz, Thyasira n. sp. from the Regab site in the Gulf of Guinea (3167 m depth), and Thyasira n. sp. Guiness from the Guiness site, at $580 \mathrm{~m}$ depth in the Gulf of Guinea (Brissac et al., 2011; Distel and Wood, 1992; Duperron et al., 2012; Rodrigues and Duperron, 2011). Each of these species has a single dominant bacterial 16S rRNA phylotype (Fig. 2). A certain level of within-species strain heterogeneity could exist, as shown by the co-occurrence of two highly similar yet distinct phylotypes in Thyasira n. sp. Guiness (Duperron et al., 2012). Interestingly, symbionts cluster in at least three clearly distinct clades within the Gammaproteobacteria, four if we include Symbiont I of Maorithyas hadalis (Fig. 2). Sequences from T. flexuosa and Thyasira aff. flexuosa from the eastern Mediterranean cluster with various sequences from Lucinidae and Siboglinidae symbionts, and with environmental sequences. The symbiont of Thyasira sp. Guiness clusters with those of Thyasira n. sp. Regab and Maorithyas hadalis, close to environmental sequences from reducing habitats. Interestingly, the symbiont of $T$. vulcolutre clusters right within the clade of Vesicomyidae-associated symbionts, suggesting a recent host shift from Vesicomyidae to Thyasiridae (Rodrigues and Duperron, 2011). Because T. vulcolutre co-occurs with Vesicomyidae in the Gulf of Cadiz, host shift could have resulted from lateral acquisition. Symbiont phylogeny thus suggests multiple independent origins of symbiotic bacteria associated with the Thyasiridae, possibly from a pool of environmental bacteria presenting features that allow them to establish interactions with metazoans (Imhoff et al., 2003; Rodrigues and Duperron, 2011). This observation agrees well with the hypothesis of the multiple origin of symbiosis in Thyasiridae hosts. Thyasira flexuosa, in particular, seems to be a species with a wide geographical distribution (Fig. 1), occurring in the western Atlantic in Florida, in the eastern Atlantic from Norway south to Galicia (Spain), and in the Mediterranean near the Iberian peninsula (Dufour, 2005; Southward, 1986). This could make T. flexuosa a good target species to investigate the relevance of the AEB hypothesis to Thyasiridae.
Occasionally, additional bacterial sequences are recovered, mostly Epsilonproteobacteria and Bacteroidetes, but fluorescence in situ hybridization has yet to support these as being significant symbionts (Brissac et al., 2011; Rodrigues and Duperron, 2011). Microscopy also indicates possible Spirochete-like morphotypes located extracellularly on the apex of some bacteriocytes. Interestingly, at least four studies report the presence of dense virus-like inclusions within bacteria of Thyasira from four different locations: T. flexuosa from Plymouth Sound (15 m depth) and $T$. gouldi from Loch Etive, Scotland (Southward and Southward, 1991), off Long Beach, Florida (Dufour, 2005), and Thyasira sp. at cold seeps in the eastern Mediterranean (central zone, site 2A, $1693 \mathrm{~m}$ depth) (Brissac et al., 2011). In all cases, dodecahedral inclusions occur only in some bacteriocytes, but are abundant when present. Brissac et al. (2011) indicated that these "infected" bacteriocytes displayed large lysosomal structures, possibly involved in the destruction of infected symbionts. Viral infection of symbionts is thus a recurrent feature of Thyasiridae symbioses. Another intriguing finding is the presence of peculiar gill cells displaying large and abundant mitochondria, unlike the situation in "normal" bivalve gills (Southward, 1986). For example in Mendicula ferruginosa, which is devoid of symbionts, it has been hypothesized that these structures might be generating ATP by oxidizing reduced compounds such as reduced iron, although this remains to be proven (P. R. Dando, personal communication, 2013).

\subsection{Lucinidae}

Lucinidae were formerly classified along with Thyasiridae within the Lucinoidea, mainly because of shared morphological features. However, recent molecular evidence has shown that the families, although displaying convergent features, are not closely related (Taylor and Glover, 2000; Williams et al., 2004). Lucinidae are burrowing bivalves occurring over a wide range of depths, from coastal to at least $2500 \mathrm{~m}$, and in latitudes from $60^{\circ} \mathrm{N}$ to $55^{\circ} \mathrm{S}$. More than 400 (330 living) species have been described, 85 in the area investigated here. They are the most diverse of the chemosymbiotic bivalves (reviewed in Taylor and Glover, 2006; Taylor et al., 2011). All investigated Lucinidae harbor chemoautotrophic, sulfur-oxidizing Gammaproteobacteria located within vacuoles occurring in gill epithelial cells from the lateral zone of the gill filament, suggesting obligatory association (Frenkiel and Moueza, 1995). Despite this, lucinids retain the capability to filter feed (Duplessis et al., 2004). Gills, which form about one-third of an animal's weight, are thick, opaque, and organized in bacteriocyte channels (Distel and Felbeck, 1987). Moreover, bacteria can store sulfur granules. Symbiosis studies from littoral species have been initiated on the west coast of France (e.g., Loripes lucinalis) showing the translocation of fixed carbon from bacteria to the host tissues (Herry et al., 1989), but most of our knowledge regarding 
the functioning of lucinid symbioses originates from species in the Caribbean. In vivo experiments on Codakia orbicularis demonstrated symbiont absence in ovaries, testis, eggs, veliger larvae and metamorphosed juveniles reared in sterile sand (Gros et al., 1996, 1997). Symbiont-specific PCRs also failed to reveal bacterial DNA from the testis and ovaries, and TEM did not reveal bacterial shapes in Lucinoma aequizonata (Gros et al., 1999). Overall this supports environmental acquisition of symbionts after larval metamorphosis. Free-living forms of symbionts were subsequently shown to be abundant in the Thalassia testudinum seagrass environment and water (Gros et al., 2003b). The functioning of symbiosis is also intriguing. Bacteria replicate their genomic DNA but do not divide actively within hosts cells (Caro et al., 2007), and are not released by adult bivalves (Brissac et al., 2009), suggesting a strong host control. Further, symbiont reacquisition after starvation is not by within-host division of bacterial cells, but rather by capture of new bacteria courtesy of a life-long continuous ability to acquire symbionts (Gros et al., 2012). In oxygen-depleted environments, symbionts of some species can avoid competition with their host for oxygen resources by growing on nitrate (Duplessis et al., 2004). Carbon transfer would most likely involve the digestion of symbionts.

In the area considered, symbioses have been investigated in several coastal species, mainly from the Caribbean, near Guadeloupe and Martinique. These include Lucina pectinata, which lives in black reducing sediment of mangrove swamps, and Codakia orbiculata, C. pectinella, C. orbicularis, C. costata, and Linga pensylvanica, which live in Thalassia testudinum seagrass beds. All five seagrass bed species share a single 16S rRNA symbiont phylotype (Distel et al., 1994; Durand et al., 1996). Anodontia alba (Brissac et al., 2011) and Divaricella quadrisulcata (Gros et al., 2003a), which live in reduced sediment near seagrass beds, also have identical symbionts to those of Codakia orbicularis. The symbiont from $L$. pectinata not only diverges from those of other lucinids, but the host tissue also displays a high concentration of haemoglobin, which suggests that the symbiosis might function in a different way (Frenkiel et al., 1996). Another species, L. nassula, occurs in seagrass beds near Florida and has a very similar symbiont sequence (Durand and Gros, 1996) Additionally, symbiosis was characterized based on gill tissue ultrastructure or molecular evidence in a variety of other coastal reduced sediment or seagrass bed species including Myrtea spinifera, L. floridana, L. borealis, and Loripes lucinalis (synonymized with Loripes lacteus, for which symbiont $16 \mathrm{~S}$ sequences are in GENBANK but unpublished), with estimates that the latter could be responsible for up to $16 \%$ of the primary production observed in seagrass bed habitats in a lagoon in upper Corsica (Dando et al., 1994, 1985, 1986; Distel et al., 1988; Johnson and Fernandez, 2001; Johnson et al., 2002).

Symbiosis has also been investigated in some deep-water species from the eastern Mediterranean Basin cold seeps. $\mathrm{Lu}$ - cinoma aff. kazani occurs at depths between 500 and $1709 \mathrm{~m}$ in the Anaximander Mountains between Rhodes and Cyprus, the Olimpi area south of Greece on the Mediterranean Ridge, and the Nile deep-sea fan (North Alex MV and pockmarks in the Central area); it was also recently reported from the Sea of Marmara (Bayon et al., 2009; Olu-LeRoy et al., 2004; Ritt et al., 2010; Salas and Woodside, 2002). The second species, Myrtea sp., possibly M. amorpha described in Olu et al. (2004) and Ritt et al. (2010), is closely related to $M$. spinifera based on $18 \mathrm{~S}$ and $28 \mathrm{~S}$ gene sequences, and is labeled Myrtea aff. spinifera in the tree (Fig. 2). It was sampled from the same areas as Lucinoma kazani, including the Sea of Marmara. Both $L$. aff. kazani and M. aff. spinifera harbor sulfur-oxidizing bacteria in their gills (Fig. 3b), and the ultrastructure of the association, in terms of bacterial shape, presence of sulfur granules, and host tissue organization, resembles that of shallow water lucinids. Another deep-sea species with sulfur-oxidizing symbionts, L. asapheus, is documented from Mercator MV in the Gulf of Cadiz (Rodrigues et al., 2010). In $L$. aff. kazani, a dominant bacterial endosymbiont was identified, and the presence of APS reductase- and RubisCO-encoding genes confirmed the chemoautotrophic potential of symbionts. Spirochete sequences were reported for $L$. aff. kazani and L. asapheus, but without further evidence they are unlikely to represent significant symbionts and were suggested as potential pathogens.

Seep lucinids emerged during the Jurassic period. Symbiosis has often been considered as a critical step in allowing their diversification, and could possibly even date back to the Silurian (Boss, 1970; Distel et al., 1994; Little and Vrijenhoek, 2003). From the point of view of bacteria, the situation is more complex. The host-symbiont relationship is not highly specific, as interspecific infection of aposymbiotic juveniles can occur (Gros et al., 2003a). Since symbionts do not divide inside host cells and cannot be released, symbiosis appears to be an evolutionary dead end for bacteria. Multiple related symbiont strains most probably co-occur within a given host. Although 16S rRNA usually displays no intra-individual variation, two related but distinct RubisCO form IA sequences were obtained from $L$. aff. kazani, which could suggest multiple strains (Duperron et al., 2007a). Recombination between symbionts and environmental bacteria may take place, given the incongruence between the APS reductase and 16S rRNA phylogenies from the $L$. aff. kazani symbiont. Indeed, 16S rRNA indicates a Gammaproteobacterium, while APS has a Betaproteobacterium as a closest relative (Duperron et al., 2007a). To understand the evolution of lucinid symbionts will require extended knowledge of free-living forms, as symbiosis is probably just one of several niches available for the bacteria, and possibly not an optimal one with regards to fitness. 


\section{Comparing symbioses from North Atlantic, Gulf of Mexico and Mediterranean bivalves}

\subsection{Ecological trends in bivalve symbioses}

Most chemosymbiotic bivalves associate with sulfuroxidizing bacteria (Fig. 2). They usually live in habitats existing within the oxic/anoxic interface, where animals can acquire oxygen from seawater as well as reduced sulfur compounds available in the underlying substrate (e.g., reduced sediment, decaying organic matter, seeping fluid, etc). In normal deep-sea sediment settings, this oxic/anoxic interface does not exceed a few centimeters, or just a few millimeters in undisturbed cold seep sediment with little-to-no mixing between the two layers (de Beer et al., 2006; Wenzhofer and Glud, 2002). The "feeding" behavior of chemosymbiotic burrowing-bivalves, made possible by their morphology (long siphons, extensile foot), artificially extends this oxic layer's depth, increasing access to reduced compounds while maintaining oxygenated conditions (Cavanaugh et al., 2005). Symbiotic Mytilidae are an exception not only because they can have additional symbionts, notably methanotrophs (Fig. 2), but also because they are epibenthic and usually do not burrow into the substrate. Thus, in order to maintain fluid supply to gill-inhabiting symbionts, they require actively emitted, reduced compounds mixing with oxygenated seawater. This might explain their success at many vents and seeps that are characterized by active venting, and organic falls that emit reduced compounds, and also their absence at some other seeps and among background fauna. In contrast, other families have some representatives in reduced sediments away from active seeping sites (deep-sea or even coastal sediments).

Lucinidae and Vesicomyidae are all associated with sulfuroxidizing symbionts, whatever their habitat or depth, although direct evidence is still lacking for the genus Vesicomya sensu Krylova (Decker et al., 2012; Krylova and Sahling, 2010; Taylor and Glover, 2000). Symbiont phylogeny indicates the absence of depth- or habitat-related clades (Fig. 2). By contrast, within Vesicomyidae hosts, recent phylogenies suggest recurrent events of "stepwise speciation" from shallow to deep waters in different ocean basins, consistent with narrow vertical ranges for most of the vesicomyid genera (Decker et al., 2012; Krylova and Sahling, 2010). All Solemyidae also associate with sulfuroxidizers, but the genus Acharax, which occurs at deeper sites than Solemya, is associated with a different clade of sulfur-oxidizing bacteria than members of the shallower genus (Imhoff et al., 2003). It is not known whether this difference is linked with host genus or with distinct depth ranges. In the Thyasiridae (though not all species have symbionts), symbiosis does exist in both shallow and deep-sea species, and in the various types of habitats colonized by this family. There are also non-symbiotic species in all habitats and at all depths (Dufour, 2005). Southward (1986) for example demonstrated that individuals of Thyasira ferruginea found at $1500 \mathrm{~m}$ did not harbor symbionts, and Decker and Olu (2012) did not find evidence for a major input of symbionts in the nutrition of the host based on stable isotope analysis. In the Mytilidae, multiple symbioses involving 2 to 6 bacterial types occur in the area considered in this study, and this might be peculiar to the area, as species from other regions have either sulfur- or methane-oxidizers only. Yet, multiple symbioses occur both at seeps and vents, and methanotrophs mostly at methane-rich sites (Duperron et al., 2009). Most mussels associated with organic falls harbor thiotrophic symbionts, but some may have methanotrophs (identified on some Idas modiolaeformis specimens) or other symbiont types such as Gammaproteobacteria G, and may not have thiotrophs (C. Rodrigues, personal observation, 2013). Bacterial densities can be rather low, suggesting that additional nutritional sources are probably significant. Overall depth or habitat type does not strongly influence the diversity of symbioses except in Mytilidae, in which the presence of methanotrophs is clearly linked with methaneenriched habitats, or by-products of wood degradation such as methanol.

Symbiont abundances on the other hand are clearly influenced by local characteristics of the habitat. This has been demonstrated in vent and seep Mytilidae, in which relative amounts of sulfur- versus methane-oxidizing bacteria reflect the availability of their respective substrates, and can also display age- or time-related variations (Le Bris and Duperron, 2010; Fiala-Médioni et al., 2002; Halary et al., 2008; Riou et al., 2008). Although they only have sulfur-oxidizing bacteria, Thyasiridae can also display inter-habitat variability in symbiont densities, with higher densities when sulfide is more abundant in the environment (Dufour and Felbeck, 2006). Using carbon stable isotopes ratios, Dando and Spiro (1993) have shown that the contribution of chemoautotrophic bacteria could vary inter-annually in Thyasira sarsi and $T$. equalis, in relation to environmental change in the habitat. In some specimens, carbon signatures of these symbiotic thyasirids were identical to those of non-symbiotic bivalves in which the diet was based upon phytoplanktonderived material. This was interpreted as a consequence of mixotrophy with animals that derive distinct fractions of their diet from symbionts and from heterotrophy.

\subsection{Reproduction, development and dispersal strategies of hosts}

Most documented symbiotic bivalves from the area under study are gonochoric such as Bathymodiolus azoricus (Table 1, Colaço et al., 2006; Dixon et al., 2006). A few of them are hermaphrodites alternating between being functional males and females, such as Idas modiolaeformis, a protandric hermaphrodite (Gaudron et al., 2012). Most seem to be broadcast spawners with no brooded-development detected so far. Oocytes can be large and rich in vitellus 


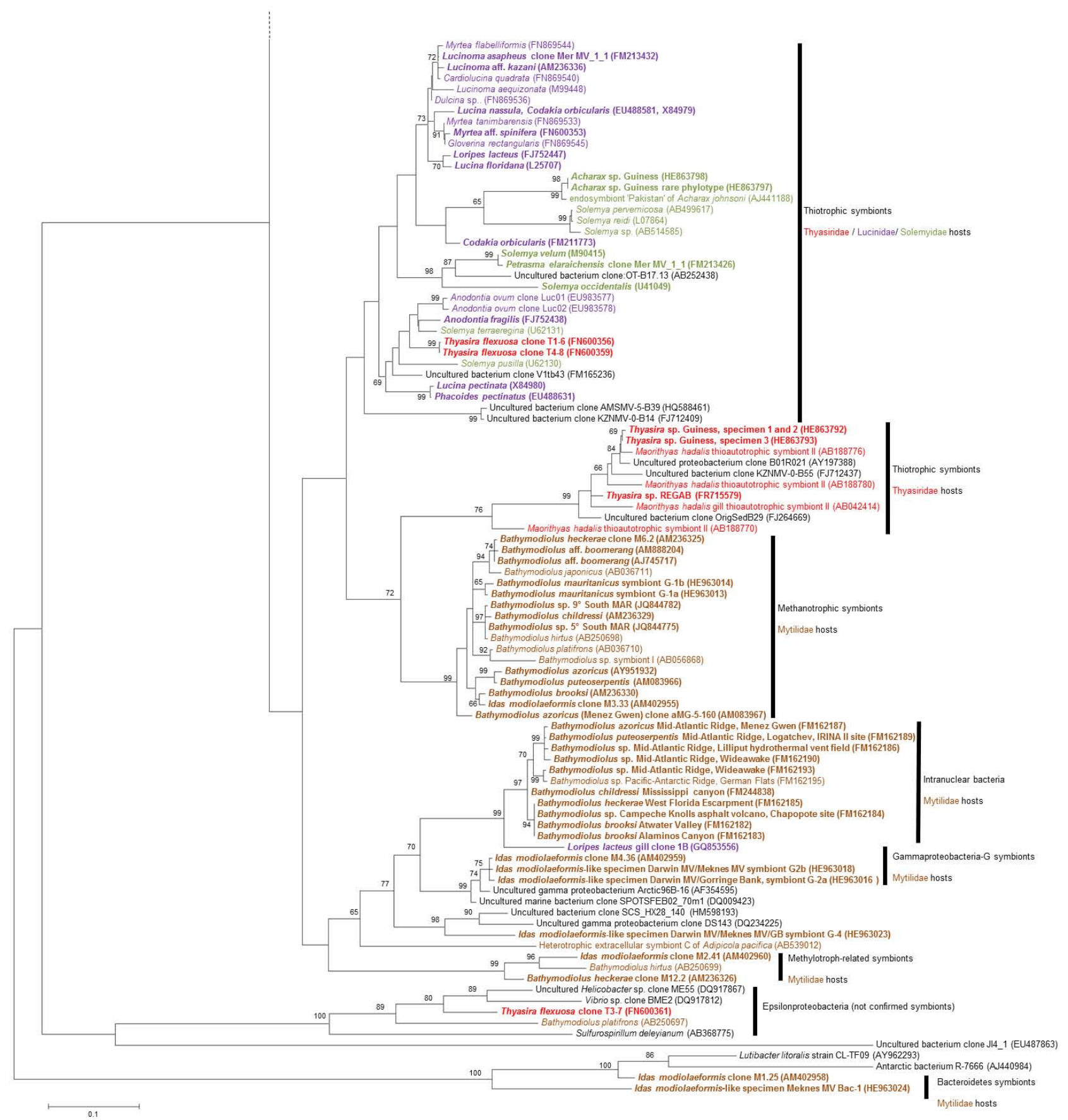

Fig. 2. Phylogeny of the Gammaproteobacteria associated with bivalve hosts based on analysis of 16S rRNA-encoding genes. Epsilonproteobacteria presented include two sequences obtained from animal tissues, but not confirmed as actual symbionts, contrary to the Mytilidaeassociated Bacteroidetes. Colors relate to the family to which the host belongs; sequences in bold are from species present in the area of focus for the review. For clarity, only host species name is mentioned without mention of "symbiont". Properly identified bivalve-associated 16S rRNA sequences above 1200 bp were used; short sequences available for Bathymodiolus tangaroa, Acharax gadirae and Idas macdonaldi were not included. Tree was reconstructed using a maximum likelihood algorithm from 1129 nucleotide positions. Based on Bayesian information criterion, a Tamura 3-parameter with Gamma-distribution of rates (T92+G) was employed. Node support values ( $>60 \%$ shown) are based on 500 bootstrap replicates using the same methodology. Analyses were run using MEGA 5.0 (Tamura et al., 2011). Although some names have recently taken on new synonyms (see Table 1), we used names included in the original GENBANK records. 
99 - Isorropodon perplexum (HE680079)

Isorropodon megadesmus (HE680078)

[L Vesicomya steamsii (AB642238)

- Isorropodon bigoti (HE680077)

- Elenaconcha guiness (HE863789)

- Vesicomya cordata (FJ899928)

97 Calyptogena ponderosa (EU403436)

Vesicomya sp. mt-III (EU403437)

84 - Calyptogena aff. angulata (AY310507)

Calyptogena nautilei (AB479080)

- Vesicomya sp. mt-l (EU403439)

95 Vesicomya sp. mt-II (EU403438)

${ }^{95}$ Calyptogena fausta (AB479081)

- Calyptogena valdiviae, specimen 1 (HE863787)

- Calyptogena valdiviae, specimen 2 and 3 (HE863786)

- Pliocardia sp. SKG-2011 (JF784423)

- Vesicomya sp. (FJ899927)

Calyptogena fossajaponica (AB044744)

${ }^{95}$ Calyptogena sp. KT (AB479078)

9 Abyssogena southwardae (JQ844765)

Calyptogena phaseoliformis (AB479082)

Vesicomya sp. mt-II (EU403434)

- Thyasira vulcolutre (FR715580)

85. Calyptogena extenta (AB479075

- Calyptogena laubieri ssp. 'CM-2 M' (AB479073)

90 Calyptogena kilmeri (EU403431)

${ }^{9}$ Calyotogena soyoae (AB479077)

99 - Calyptogena kawamurai (AB479076)

Lesicomya gigas (AF035726)

- Calyotogena packardana (AY310508)

78- Vesicomya sp. (FJ899926)

100, Bathymodiolus aff. brevior (DQ077891)

61 Bathymodiolus marisindicus (DQ321715)

L Maorithyas hadalis symbiont I (AB042413)

- Bathymodiolus aff boomerang (AJ745718)

${ }_{97}-$ Bathymodiolus heckerae clone M6.3 (AM236327)

Bathymodiolus azoricus (DQ321711)

${ }^{498}$ Bathymodiolus puteoserpentis (DQ321712)

- Bathymodiolus sp. Manus Basin (EU326223)

- Bathymodiolus brooksi (AM236331)

- Bathymodiolus thermophilus (DQ321716)

99

65 Bathymodiolus aff. thermophilus (DQ321717)

Bathymodiolus sp. $9^{\circ}$ South MAR (JQ844785)

Bathymodiolus sp. $5^{\circ}$ South MAR (JQ844772)

Bathymodiolus brevior (DQ321714)

- Bathymodiolus hirtus (AB250700)

72 Bathymodiolus seotem dierum (AB598130)

- Bathymodiolus sp. (AB073122)

Bathymodiolus aff. brevior (DQ321713)

Myrina sp. HEE-2004 (AB178222)

- Bathymodiolus mauritanicus/Idas modiolaeformis-like specimen G-3 (HE963020)

Mytilidae sp. morphotype BC 279 (AM851094)

- Idas modiolaeformis clone M1.2 (AM402956)

- Mytilidae sp. morphotype BC 288 OG60-41 (AM851093)

- Uncultured bacterium partial 16S rRNA gene, clone 336-10 (AM931532)

das sp. (EU683305)

Idas sp. (EU683307)

78 idas sp. (EU683306

- Adipicola pacifica (AB539011)

- Idas-like specimen, Marmara Sea (JQ038225)

98 Mytilidae sp. morphotype BC 1007 (AM503921

Mytilidae sp. morphotype BC 294 (AM503922)

- Bathymodiolus sp. clone: Bsp6-2 (AB499796)

${ }^{78}$ L Gigantidas gladius (EU326224)

Adipicola crypta (EU683303)

182Adipicola crypta (AB539010)

- Bathymodiolus heckerae clone M3.7 (AM236328)

- Uncultured bacterium partial 16S rRNA gene, clone Rari5_c6390 (HE814591) Uncultured SUP05 cluster bacterium clone SGST732 (GQ345623)

- Idas modiolaeformis clone M1.17 (AM402957)

Deep-sea mussel NZ3 (DQ321718)

Fig. 2. Continued. 
(Fig. 3c), indicative of lecithotrophic larval development and potentially enabling a significant larval dispersal under oligotrophic conditions in the surrounding deep sea (Beninger and Le Pennec, 1997). Alternatively, oocytes can be smaller with a lower vitellus content (Fig. 3d), indicative of planktotrophy where the veliger larvae will actively feed upon dissolved organic matter, phytoplankton, or microorganisms (Arellano and Young, 2009). Historically, planktotrophic larvae have been thought to spend an extended period in the plankton and disperse great distances, while lecithotrophic larvae live on limited reserves of vitellus, which permit limited dispersal time only before metamorphosis and settlement (Thorson, 1950, Fig. 4a). This distinction might, however, be partially inaccurate in the cold deep sea, as developmental and metabolic rates decrease with temperature, enabling longer dispersal time for lecithotrophic larvae, prior to competency and settlement, than previously thought (Le Pennec and Beninger, 2000; Tyler and Young, 1999). Much is believed to depend upon the seasonality of reproduction and whether larval dispersal takes place in cold deep waters or in warmer surface waters (Fig. 4a, Tyler et al., 2007). Currently, however, such information is scarce for chemosymbiotic bivalves.

Vesicomyidae, Solemyidae and Lucinidae bivalves generally have large oocytes (from $100 \mu \mathrm{m}$ up to $600 \mu \mathrm{m}$ diameter) rich in yolk (Table 1, Fig. 3c), although a few exceptions occur (Le Pennec and Beninger, 2000). Most Vesicomyidae seem to be continuous spawners, but some also display periodicity like Calyptogena pacifica and Calyptogena kilmeri from bathyal depths in Monterey Bay (Lisin et al., 1997). The large oocyte size in several species indicates that the veliger larva is probably lecithotrophic. To date, no data are available regarding their dispersal capacities (Lisin et al., 1997; Parra et al., 2009). The protobranch family Solemyidae has a pericalymma larva. In Solemya velum the embryo develops within a sticky and negatively buoyant gelatinous capsule on the seafloor and yields a juvenile stage resembling the adult and possessing gill symbionts (Gustafson and Lutz, 1992; Krueger et al., 1996b). This capsule, being adhesive, may disperse in the ocean if it has been initially attached to organic matter or sediment particles that may be resuspended and transported by water currents. The shallow-water S. velum is widespread in the northwest Atlantic, from northern Florida to Nova Scotia, and larval dispersal conforms to that of a passive particle. Gelatinous egg capsules are also observed in the tropical Lucinidae from the Caribbean such as Codakia orbicularis (Gros et al., 1997), and in the shallowwater Thyasiridae from the North Atlantic, Thyasira gouldi (Blacknell and Ansell, 1974, Fig. 3e). Little data exists regarding dispersal capacities in both families. Mytilidae have planktotrophic larvae, and the time spent in the water column has been inferred from the relative sizes of prodissoconch I and II (Fig. 3f). The granular prodissoconch I is produced from the energy reserves of the oocytes, while prodissoconch II develops incrementally, using energy from food during the

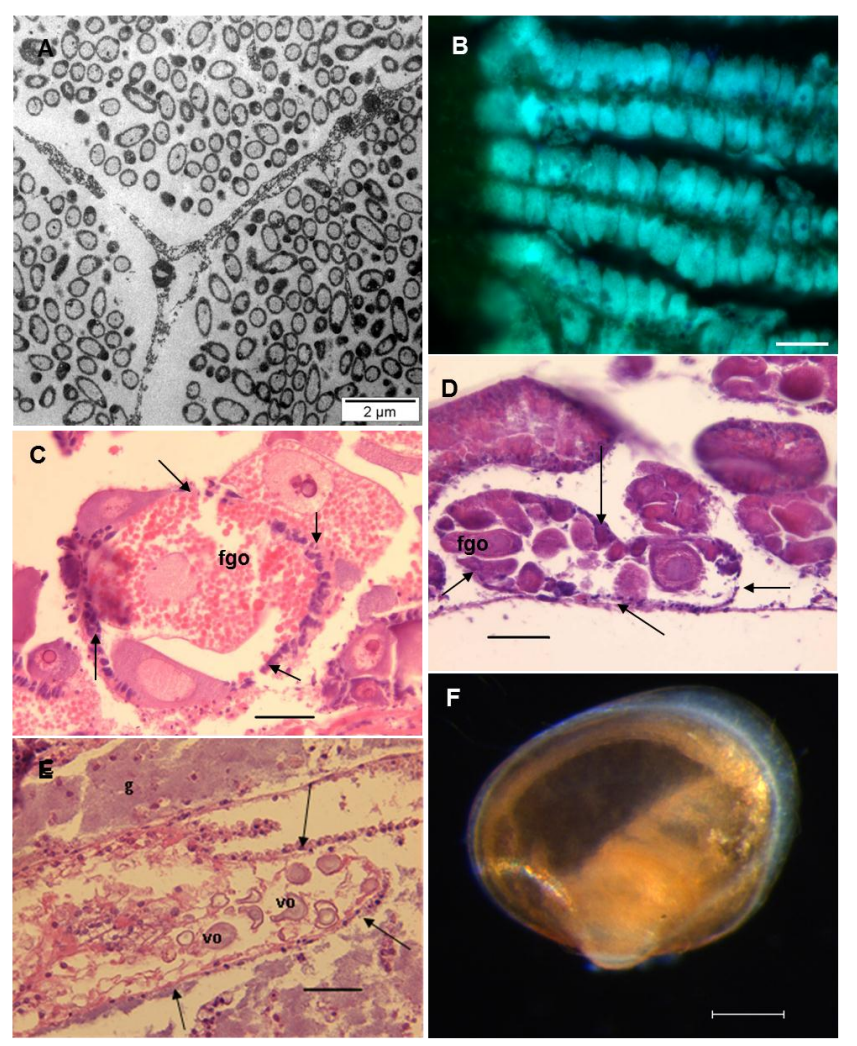

Fig. 3. (A) Detail of sulfur-oxidizing symbionts associated with gill filaments of Thyasira sp. Regab (Thyasiridae) under the TEM. (B) Fluorescence in situ hybridization using a symbiont-specific probe on a cross section through 3 gill filaments of Myrtea spinifera (Lucinidae) showing the dense populations of bacteria in the lateral zone. Scale bar $=50 \mu \mathrm{m}$. (C-E) Histological sections of female gonads stained with hematoxylin-eosin. Scales bars are $50 \mu \mathrm{m}$. (C) Detail of an acinus (arrows delimiting) encompassing a large lecithotrophic oocyte (fgo: fully grown oocytes of $\sim 150 \mu \mathrm{m}$ diameter) in Isorropodon bigoti (Vesicomyidae). (D) Detail of an acinus (arrows delimiting) encompassing smaller fully grown oocytes (fgo; $\sim 60 \mu \mathrm{m}$ diameter) in Idas modiolaeformis (Mytilidae) that has a planktotrophic larvae. (E) Detail of a gonad (arrows delimiting) encompassing small vitellogenic oocytes (vo) $\sim 20$ to $30 \mu \mathrm{m}$ diameter in Thyasira sp. nov. from the Guiness site (Thyasiridae, $\mathrm{g}$ for gills). (F) Early juvenile of Idas modiolaeformis, with prodissoconch II visible in orange and the surrounding young dissoconch in white. Notice the low number of gill filaments visible by transparency. Scale bar $=100 \mu \mathrm{m}$.

free-swimming larval form (Arellano and Young, 2009; Gaudron et al., 2012; Lutz et al., 1980; Ockelmann, 1965). Experimental evidence demonstrated that Bathymodiolus childressi from the Gulf of Mexico can produce "teleplanic" larvae capable of spending one year in the water column before settlement, supporting long-distance larval dispersal capabilities (Arellano and Young, 2009). It was subsequently shown that temperature is not a limiting factor in the vertical 
migration of larvae up to $100 \mathrm{~m}$ or more above the cold seeps in the Gulf of Mexico (Arellano and Young, 2011).

Investigating dispersal patterns of bivalve hosts is problematic. Early larvae and dispersal stages of chemosymbiotic bivalves are difficult to identify in the water column, despite various methodologies based on diagnostic PCR, or in situ hybridization of larvae using specific probes having been developed (Comtet et al., 2000; Le Goff-Vitry et al., 2007; Pradillon et al., 2007). Consequently, the distributions of larvae and their positioning in the water masses are not known. The factors triggering larval settlement at a new site are poorly understood, although several authors suggest that sulfide or plume compounds may play a role (Cowen and Sponaugle, 2009; Tyler and Young, 1999; Won et al., 2003). Theoretical approaches have attempted to evaluate dispersal potential, but with severe limitations (Martins et al., 2008). For example, a recent Lagrangian-based dispersal model implemented for the Gulf of Mexico mussel Bathymodiolus childressi indicated that despite long larval life, larvae released from relatively shallow seep habitats of the species $(100$ and $500 \mathrm{~m}$ ) tended to be retained in the Gulf of Mexico, limiting the potential for trans-Atlantic dispersal (Young et al., 2012). In an earlier study, several planktotrophic gastropod larvae, similar in size and shape, were shown to be capable of crossing and dispersing throughout the Atlantic using diverse currents, indicating that the hypothesis for transAtlantic dispersal needs to be considered (Scheltema, 1971). Dispersal potential also depends upon the depth at which larvae live and, critically, whether or not they rise up the water column. Evaluating biological parameters needed to inform dispersal, including data concerning buoyancy, swimming behavior, duration of larval stage, age at competency, transport mode, or feeding strategy, is critical for accurate predictions, thus emphasizing the need for more experimental work. The distribution of adults, although patchy and far from being fully documented, can only provide clues, and thus alone is not sufficient.

\subsection{Acquisition of symbionts}

Bacteria have been detected in the ovaries and follicle cells of Vesicomyidae. In Solemya reidi, bacteria are found in ovaries, eggs, larvae and in juvenile stages. Bacteria occur in the ciliated epithelial calymma surrounding the 3 day pericalymma larvae. Inoculation by digestion of the calymma during metamorphosis of the larvae was proposed, whereby symbionts were subsequently transported to the developing gills (Gustafson and Reid, 1988; Stewart and Cavanaugh, 2006). As already discussed, maternal inheritance in Vesicomyidae has triggered genome reduction in symbionts, potentially limiting their ability to occur in a free-living form. This has not yet been identified in Solemya symbionts (Kleiner et al., 2012). Environmental acquisition implies the existence of free-living forms of the symbionts (Fig. 4b). Acquisition can start early in life, but the ability to acquire
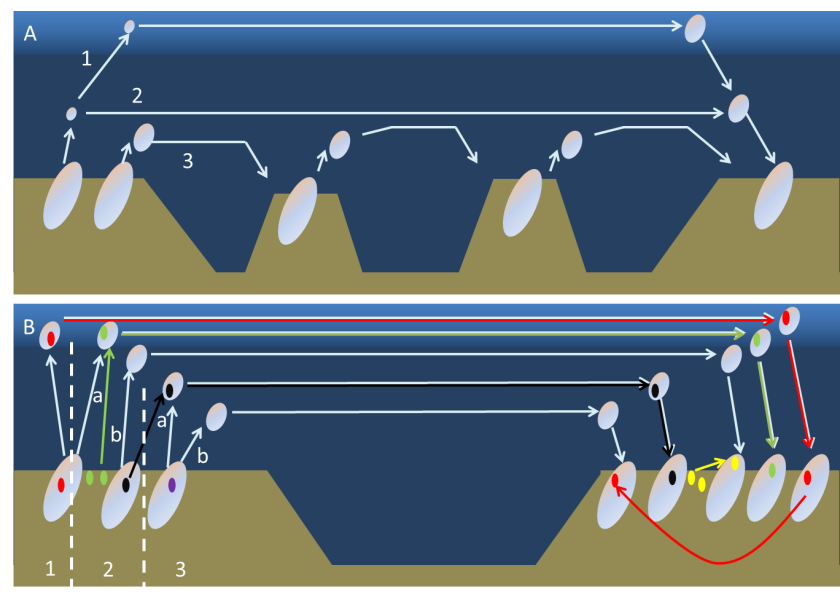

Fig. 4. (A) Dispersal strategies in bivalves. Long-distance, with planktotrophic larvae dispersing in the euphotic zone (1) or in a deeper water layer (2). Larvae can grow during dispersal and can settle very far from their birth site. Shorter-distance dispersal (3) can be achieved by lecithotrophic larvae, which live on maternal reserves and theoretically settle closer to their birth site. (B) Bacterial symbionts can be maternally inherited (1), acquired from freeliving populations of bacteria at site of origin ( $2 \mathrm{a}$, green bacterium) or at site of settlement ( $2 \mathrm{~b}$, yellow bacterium), or laterally acquired from another host at site of origin ( $3 \mathrm{a}$, black bacterium) or at site of settlement ( $3 b$, red bacterium). Situations 1, 2a and $3 a$ lead to host-symbiont co-dispersion, as emphasized by the bi-color arrows. Different transmission modes can co-exist within a given species.

bacteria seems to be retained during adult life in certain bivalves. Indeed, symbiont-depleted Lucinidae were shown to reacquire symbionts exclusively via endocytosis throughout their life, and acquired bacteria do not divide inside the gill (Brissac et al., 2009; Caro et al., 2007). In the Mytilidae, many authors suggest that symbiont uptake occurs early in life (Fig. 4b, Salerno et al., 2005). However, repeated observations of abundant endocytosis vacuoles engulfing bacteria in adult gill epithelial cells suggest that symbiont uptake may also occur in adults (Dubilier et al., 1998; Fiala-Médioni et al., 2002). An increase in symbiont numbers after a period of starvation also occurs through within-gill bacterial division (Kadar et al., 2005). Recent results indicate that maternal and environmental modes of acquisition are not mutually exclusive. In Vesicomyidae, lateral acquisition of non-parental symbiont strains, probably promoted by physical closeness, has been documented in several species (Fig. 4b, Stewart et al., 2008; Decker et al., 2013).

\subsection{Connectivity}

Several metazoan species or sister species were shown to occur on both sides of the Atlantic, suggesting the existence of preferential dispersal pathways across the Atlantic equatorial belt (Cordes et al., 2007; Olu et al., 2010; OluLeRoy et al., 2007b, Fig. 1). In chemosymbiotic bivalves 
for which symbiosis is documented, at least three Mytilidae groups are known: the species complexes Bathymodiolus childressi/B. mauritanicus (Gulf of Mexico, Barbados prism, Nigerian margin and Gulf of Cadiz), B. boomerang/B. heckerae (Gulf of Mexico, Barbados prism, Blake Ridge and Gulf of Guinea), and Idas macdonaldi/I. modiolaeformis (Gulf of Mexico, Gulf of Cadiz and Mediterranean) (Cordes et al., 2007; Van Dover et al., 2003; Génio et al., 2008; Lorion et al., 2012; Olu-LeRoy et al., 2007b). These examples provide important insights into the speciation and the evolutionary context for the present biogeography of chemosynthetic mytilids in the area of interest. Given the planktotrophic larval development and the estimated duration of larval stages of $1 \mathrm{yr}$ in B. childressi and at least 5 months in Idas modiolaeformis, the potential for larvae to cross the Atlantic exists. Barriers to dispersal probably occur, though the Strait of Gibraltar at least does not prevent Idas modiolaeformis from occurring on both the Atlantic and Mediterranean side, suggesting occurrence of larvae in upper seawater layers (shallowest depth: $300 \mathrm{~m}$ ). A non-exclusive alternative would be that intermediate populations occur at sites situated between the extremes of the reported distribution. This hypothesis was raised upon discovery of the relationship between Idas modiolaeformis and I. macdonaldi, and confirmed by the discovery of I. modiolaeformis specimens in the Gulf of Cadiz, and in the Lacaze-Duthiers Canyon in the western Mediterranean (Rodrigues et al., 2013; N. Le Bris, personal communication, 2012). Abyssogena southwardae, occurring on the west coast of Florida, in the Barbados prism, along the MAR, from $5^{\circ} \mathrm{S}$ to $14^{\circ} \mathrm{N}$, to near the Canary islands, could be example of a Vesicomyidae with an amphi-Atlantic distribution. However, molecular data are not available from all locations, preventing rigorous testing of the hypothesis (van der Heijden et al., 2012; Krylova et al., 2010). A. southwardae probably has lecithotrophic larvae with a limited dispersal potential, but locations are separated by relatively short distances that may be within the limits of larval dispersal capacity, particularly considering the advantage of lecithotrophy in oligotrophic deep-sea waters (Tyler and Young, 1999). Volcanic seamounts (Henry Seamount near the Canary Islands), transform faults or other sulfide-enriched habitats such as organic remains may act as ecological and/or evolutionary stepping stones between the known seeps and vent localities (Fig. 4a). Thyasira flexuosa is found from Florida to the North Sea and in the Mediterranean, suggesting it is not only an amphiAtlantic species, but also capable of crossing the Strait of Gibraltar. Similarly, lecithotrophic larvae of the deep-sea lucinid Lucinoma kazani from the eastern Mediterranean seem to be able to cross the Dardanelles, since the species has been recovered in cold seeps in the Sea of Marmara, as has the small deep-sea vesicomyid Isorropodon perplexum (Brissac et al., 2011; Ritt et al., 2010; Rodrigues et al., 2012).

Regarding their symbionts, a few clades show similar trans-Atlantic distributions (Fig. 2). Both sulfur- and methane-oxidizing symbionts in the amphi-Atlantic Mytili- dae clade Bathymodiolus heckerae (GoM)/B. aff. boomerang (GoG) are closely related on both sides of the Atlantic. The methanotroph associated with $B$. mauritanicus (GoC) is not closely related to that of its neighboring species $B$. childressi (GoM), but the later is related to bacteria associated with Bathymodiolus from the southern Mid-Atlantic Ridge vent sites $5^{\circ} \mathrm{S}$ and $9^{\circ} \mathrm{S}$. Methanotrophs of B. brooksi (GoM) and Idas modiolaeformis (Med) are also closest relatives. In Vesicomyidae symbionts, the only example is that of the Elenaconcha guiness (GoG) symbiont, which is closely related to those of Pliocardia cordata and Pliocardia ponderosa (GoM), though with low support (Fig. 2). In Solemyidae, symbionts of Solemya velum (WA) are closely related to symbionts of Solemya (Petrasma) elarraichensis (GoC). No such relationships occur among reported Thyasiridae and Lucinidae symbionts. Apart from these examples, other $16 \mathrm{~S}$ rRNA symbiont phylotypes are mixed with no self-evident trend. Symbiont-containing clades include a mixture of phylotypes associated with hosts from various locations. This might be due to the limited amount of variation of the $16 \mathrm{~S}$ rRNA gene, and maybe faster evolving genes could provide better estimates of symbiont biogeographical trends, as shown in Solemyidae from the coast of New England (Stewart et al., 2009a). However, at this stage, in contrast to observations in some host bivalves, there is no apparent trend towards closer phylogenetic relationships between symbionts from the western and eastern Atlantic. Apart from the few examples listed above, the hypothesis of a preferential dispersal or diversification route along the Atlantic equatorial belt does not appear to be relevant to the bacterial symbionts of bivalves.

Published symbiont phylogenies illustrate the close relationship between the different clades of symbionts and various free-living bacteria (Fig. 2, Petersen et al., 2012). Symbiosis with bivalve hosts has appeared independently in several clades of Gammaproteobacteria, generally consisting of sulfur-oxidizing bacteria. In most cases, symbionts derive from free-living bacteria, but in a few instances symbionts seem to have passed from one host family to another, as seen for the symbiont of Thyasira vulcolutre, which seems to have been derived from Vesicomyidae-associated bacteria (Rodrigues and Duperron, 2011). Host shifts might also have occurred within the group that includes symbionts from Solemyidae, Lucinidae and Thyasiridae, and possibly from Mytilidae to Vesicomyidae (Fig. 2). Based on the few genomes available, symbionts tend to share highly similar pathways for sulfur-oxidation, and a somewhat altered Calvin-Benson-Bassham cycle for autotrophy using either Type I or Type II RubisCO (Kleiner et al., 2012). These pathways are less diverse than documented in available genomes from related free-living bacteria. Furthermore, phylogenies obtained using functional genes (for example those encoding APS reductase, RubisCO and particulate methane mono-oxygenase) usually do not corroborate those obtained based on the classical marker $16 \mathrm{~S}$ rRNA. This suggests that 
pathway convergences among symbionts result from lateral gene transfer of pathways rather than common ascendance. In fact recombination is documented among closely related symbionts (Stewart et al., 2009b). Loss of genes is a consequence of genome reduction, documented in maternally inherited Vesicomyidae symbionts, as well as in environmentally acquired mussel-associated sulfur-oxidizers (Kleiner et al., 2012). Free-living forms of thiotrophic symbionts are documented convincingly in Lucinidae in coastal seagrass beds, and strongly suspected in Mytilidae based on data from hydrothermal vent mats and mats attached to the back of annelids, although their abundance, metabolism, and exact ecological niche are not known (Crépeau et al., 2011; Gros et al., 2003b; Petersen et al., 2012). Overall, it seems that, apart from a few cases (maternally inherited Vesicomyidae symbionts), symbionts have evolved quite separately from their hosts. Many symbionts have, or probably had, free-living forms, whereas hosts require their bacteria. This asymmetry between hosts and symbionts remains poorly acknowledged in evolutionary studies, and a better understanding of symbiont evolution will require addressing the biology of these free-living forms.

\section{Conclusions}

Chemosymbiotic bivalves are diverse. Four of the five welldocumented families are associated with sulfur-oxidizing Gammaproteobacteria. Members of the family Mytilidae (clade Bathymodiolinae) are characterized by a broader diversity of associated bacteria. Approximately 200 species belonging to these families (considering only subfamily Bathymodiolinae for Mytilidae) are documented from the North Atlantic, Gulf of Mexico and Mediterranean. Data regarding symbiosis are available for $26.5 \%$ of these species. Despite many similarities, important differences exist between bivalve families with regards to host behavior, reproductive biology and larval dispersal capabilities. Important differences also exist among their symbioses, with regards to the mode of acquisition, the establishment and the functioning of their bacterial partners. These differences might allow resource partitioning among the species that sometimes co-occur at a given site. Altogether, the level of host-symbiont specificity and inter-dependency is variable among bivalve hosts. Different families illustrate different patterns of host-symbiont association. It is crucial for future studies to consider the particular question of asymmetry in the relationship between host and symbionts. Indeed, in many cases the symbiosis is obligatory for one partner but not for the other, as seen in some Mytilidae and Lucinidae that apparently need their symbionts, whereas bacteria can also live outside their host. This certainly has far-reaching consequences for the ecology, biogeography, and evolution of these symbiotic systems.

Most of today's knowledge has been obtained on a very limited number of "model species" presented as paradigms for the characteristics of their respective families. This approach had yielded detailed knowledge of these systems. However, recent results emphasize significant within-family variability in symbiotic interactions, which may have been overlooked in the past. In this synthesis, it appears that the more diverse families are those for which a lower proportion of species has been investigated: $19.0 \%$ and $15.2 \%$ of Lucinidae and Thyasiridae (85 and 59 species, respectively) against $39.3,54.5$ and $61.1 \%$ of Vesicomyidae, Solemyidae and Mytilidae (clade Bathymodiolinae). Even focusing only on the northern Atlantic, Gulf of Mexico and Mediterranean, much more can be learned from within- and among-family comparisons in terms of common trends and peculiarities. Aside from the necessary in-depth studies carried out on selected representative species, family-scale comparative studies appear equally important to develop an integrated view of bivalve symbioses encompassing the true diversity of species and associations within each family. This broader perspective is intrinsic to concerns about marine biodiversity and conservation, which have triggered considerable effort through programs such as the Census of Marine Life (German et al., 2011). At a time when many human activities (including pollution, over-fishing, and offshore gas, petroleum, and mineral exploitation) threaten the world's oceans, a better understanding of bivalve symbioses is needed to evaluate the capacities of these remarkable ecological and evolutionary units to withstand environmental change.

Acknowledgements. Authors thank the EU programs Mediflux, HERMES, HERMIONE for funding, as well as the ESF/FCT EuroDEEP CHEMECO. We are grateful to other funding resources, the BIOZAIRE program (Ifremer), French ANR DeepOases (PI: D. Desbruyères), GDR Ecchis, Portuguese Fundação para a Ciência e a Tecnologia (FCT post doctoral fellowship SFRH/BPD/64154/2009). We acknowledge UPMC, CNRS, Ifremer and U. Aveiro for additional funding. We also thank crews, pilots and scientists of the cruises Nautinil (chief scientist: J. P. Foucher), DeepSeeps (C. R. Fisher), Bionil (A. Boetius), Medeco (J. Sarrazin and C. Pierre), Biozaire 2 (M. Sibuet), Guineco (A. Boetius), WACS (K. Olu), TTR14-17 (M. Ivanov) and MSM1/3 (O. Pfannküche) during which we collected the material on which this synthesis is based. We thank K. Szafranski, and E. Demoyencourt for providing pictures, and S. Laming for pictures and for editing the manuscript. We also thank C. Pierre for ongoing support.

Edited by: R. Serrão Santos

\section{References}

Arellano, S. M. and Young, C. M.: Spawning, development, and the duration of larval life in a deep-sea cold-seep mussel, Biol. Bull., 216, 149-162, 2009.

Arellano, S. M. and Young, C. M.: Temperature and salinity tolerances of embryos and larvae of the deep-sea mytilid mussel "Bathymodiolus" childressi, Mar. Biol., 158, 2481-2493, 2011. 
Audzijonyte, A., Krylova, E. M., Sahling, H., and Vrijenhoek, R. C.: Molecular taxonomy reveals broad trans-oceanic distributions and high species diversity of deep-sea clam (Bivalvia: Vesicomyidae: Pliocardiinae) in chemosynthetic environmanets, Syst. Biodiv., 10, 403-415, 2012.

Baco, A. R., Smith, C. R., Peek, A. S., Roderick, G. K., and Vrijenhoek, R. C.: The phylogenetic relationships of whale-fall vesicomyid clams based on mitochondrial COI DNA sequences, Mar. Ecol.-Prog. Ser., 182, 137-147, 1999.

Bayon, G., Loncke, L., Dupré, S., Caprais, J. C., Ducassou, E., Duperron, S., Etoubleau, J., Foucher, J. P., Fouquet, Y., Gontharet, S., Henderson, G. M., Huguen, C., Klaucke, I., Mascle, J., Migeon, S., Olu, K., Ondréas, H., Pierre, C., Sibuet, M., Stadnitskaia, A., and Woodside, J.: Multi-disciplinary investigation of fluid seepage on an unstable margin: The case of the Central Nile deep sea fan, Mar. Geol., 261, 92-104, 2009.

Beninger, P. G. and Le Pennec, M.: Reproductive characteristics of a primitive bivalve from a deep-sea reducing environment: giant gametes and their significance in Acharax alinae (Cryptodonta: Solemyidae), Mar. Ecol.-Prog. Ser., 157, 195-206, doi:10.3354/meps 157195, 1997.

Blacknell, W. M.: Aspects of the biology of Thyasira gouldi (Philippi) and its copepod parasite Axinophilus thyasirae (Bresciani \& Ockelmann), Ph.D. thesis, University of Sterling, 1973.

Blacknell, W. M. and Ansell, A. D.: The direct development of the bivalve Thyasira gouldi, Thalassia Jugoslavia, 10, 23-43, 1974.

Boss, K. J.: Fimbria and its lucinoid affinities (Mollusca; Bivalvia), Breviora, 350, 1-16, 1970.

Brissac, T., Gros, O., and Merçot, H.: Lack of endosymbiont release by two Lucinidae (Bivalvia) of the genus Codakia: consequences for symbiotic relationships, FEMS Microbiol. Ecol., 67, 261-267, 2009.

Brissac, T., Rodrigues, C. F., Gros, O., and Duperron, S.: Characterization of bacterial symbioses in Myrtea sp. (Bivalvia: Lucinidae) and Thyasira sp. (Bivalvia: Thyasiridae) from a cold seep in the eastern Mediterranean, Mar. Ecol., 32, 198-210, 2011.

Brooks, J. M., Kennicutt, M. C., Fisher, C. R., Macko, S. A., Cole, K., Childress, J. J., Bidigare, R. R., and Vetter, R. D.: Deep sea hydrocarbon seep communities: evidence for energy and nutritional carbon sources, Science, 238, 1138-1142, 1987.

Carney, S. L., Formica, M. I., Divatia, H., Nelson, K., Fisher, C. R., and Schaeffer, S. W.: Population structure of the mussel "Bathymodiolus" childressi from gulf of Mexico hydrocarbon seeps, Deep-Sea Res. I, 53, 1061-1072, 2006.

Caro, A., Gros, O., Got, P., De Wit, R., and Trousselier, M.: Characterization of the population of the sulfur-oxidizing symbiont of Codakia orbicularis (Bivalvia, Lucinidae) by single-cell analyses, Appl. Env. Microbiol., 73, 2102-2109, 2007.

Cary, S. C.: Vertical transmission of a chemoautotrophic symbiont in the protobranch bivalve, Solemya reidi, Mol. Mar. Biol. Biotechn., 3, 121-130, 1994.

Cary, S. C., Fisher, C. R., and Felbeck, H.: Mussel growth supported by methane as sole carbon and energy source, Science, 240, 7880, 1988.

Cavanaugh, C. M.: Symbiotic chemoautotrophic bacteria in marine invertebrates from sulphide-rich habitats, Nature, 302, 58-61, 1983.
Cavanaugh, C. M., Levering, P. R., Maki, J. S., Mitchell, R., and Lidstrom, M. E.: Symbiosis of methylotrophic bacteria and deepsea mussels, Nature, 325, 346-347, 1987.

Cavanaugh, C. M., Abbott, M. S., and Veenhuis, M.: Immunochemical localization of ribulose-1,5-bisphosphate carboxylase in the symbiont-containing gills of Solemya velum (Bivalvia: Mollusca), P. Natl. Acad. Sci. USA, 85, 7786-7789, 1988.

Cavanaugh, C. M., McKiness, Z. P., Newton, I. L. G., and Stewart, F. J.: Marine chemosynthetic symbioses, in: The Prokaryotes: an evolving electronic resource for the microbiological community, edited by: Dworkin, M., Springer-Verlag, New York, 2005.

Childress, J. J. and Mickel, T. L.: Oxygen and sulfide consumtion rates of the vent clam Calyptogena magnifica, Mar. Biol. Lett., 3, 73-79, 1982.

Childress, J. J., Fisher, C. R., Brooks, J. M., Kennicutt II, M. C., Bidigare, R., and Anderson, A. E.: A methanotrophic marine molluscan (Bivalvia, Mytilidae) symbiosis: Mussels fueled by gas, Science, 233, 1306-1308, 1986.

Childress, J. J., Fisher, C. R., Favuzzi, J. A., Arp, A. J., and Oros, D. R.: The role of a zinc-based, serum bomed sulphide-binding component in the uptake and transport of dissolved sulphide by the chemuautotrophic symbiont-containing clam Calyptogena elongata, J. Exp. Biol., 179, 131-158, 1993.

Colaço, A., Martins, I., Laranjo, M., Pires, L., Leal, C., Prieto, C., Costa, V. Lopes, H., Rosa, D., Dando P. R., and Santos R. S. Annual spawning of the hydrothermal vent mussel, Bathymodiolus azoricus, under controlled aquarium, conditions at atmospheric pressure, J. Exp. Mar. Biol. Ecol., 333, 166-171, 2006.

Comtet, T., Jollivet, D., Khripounoff, A., and Segonzac, M.: Molecular and morphological identification of settlement-stage vent mussel larvae, Bathymodiolus azoricus (Bivalvia Mytilidae), preserved in situ at active vent fields on the Mid-Atlantic Ridge, Limnol. Oceanogr., 45, 1655-1661, 2000.

Connelly, D. P., Copley, J. T., Murton, B. J., Stansfield, K., Tyler, P. A., German, C. R., Van Dover, C. L., Amon, D., Furlong, M., Grindlay, N., Hayman, N., Hühnerbach, V., Judge, M., Le Bas, T., McPhail, S., Meier, A., Nakamura, K., Nye, V., Pebody, M., and Pedersen, R. B.: Hydrothermal vent fields and chemosynthetic biota on the world's deepest seafloor spreading centre, Nat. Commun., 3, 620, doi:10.1038/ncomms1636, 2012.

Conway, N., McDowell Capuzzo, J., and Fry, B.: The role of endosymbiotic bacteria in the nutrition of Solemya velum: evidence for a stable isotope analysis of endosymbionts and host, Limnol. Oceanogr., 34, 249-255, 1989.

Conway, N., Howes, B., Capuzzo, J., Turner, R., and Cavanaugh, C.: Characterization and site description of Solemya borealis (bivalvia, Solemyidae), another bivalve-bacteria symbiosis, Mar. Biol., 112, 601-613, 1992.

Cordes, E. E., Carney, S. L., Hourdez, S., Carney, R., Brooks, J. M., and Fisher, C. R.: Cold seeps of the deep Gulf of Mexico: community structure and biogeographic comparisons to Atlantic equatorial belt seep communities, Deep-Sea Res. I, 54, 637-653, 2007.

Cordes, E. E., Becker, E. L., Hourdez, S., and Fisher, C. R.: Influence of foundation species, depth, and location on diversity and community composition at Gulf of Mexico lower-slope cold seeps, Deep-Sea Res. II, 57, 1870-1881, 2010. 
Cosel, R. V.: A new species of bathymodioline mussel (Mollusca, Bivalvia, Mytilidae) from Mauritania (West Africa), with comments on the genus Bathymodiolus Kenk \& Wilson, 1985, Zoosystema, 24, 259-271, 2002.

Cosel, R. V. and Olu, K.: Gigantism in Mytilidae. A new Bathymodiolus from cold seep areas on the Barbados accretionary Prism, C. R. Biol., 321, 655-663, 1998.

Cosel, R. V. and Olu, K.: A new genus and new species of Vesicomyidae (Mollusca, Bivalvia) from cold seeps on the Barbados accretionary prism, with comments on other species, Zoosystema, 30, 929-944, 2008.

Cosel, R. V. and Olu, K.: Large Vesicomyidae (Mollusca: Bivalvia) from cold seeps in the Gulf of Guinea off the coasts of Gabon, Congo and northern Angola, Deep-Sea Res. II, 56, 2350-2379, 2009.

Cosel, R. V. and Salas, C.: Vesicomyidae (Mollusca?: Bivalvia) of the genera Vesicomya, Waisiuconcha, Isorropodon and Callogonia in the eastern Atlantic and the Mediterranean, Sarsia, 86, 333-366, 2001.

Cowen, R. K. and Sponaugle, S.: Larval Dispersal and Marine Population Connectivity, Annu. Rev. Mar. Sci., 1, 443-466, 2009.

Craddock, C., Hoeh, W. R., Gustafson, R. G., Lutz, R. A., Hashimoto, J., and Vrijenhoek, R. J.: Evolutionary relationships among deep-sea mytilids (Bivalvia?: Mytilidae) from hydrothermal vents and cold water methane/sulfide seeps, Mar. Biol., 121, 477-485, 1995.

Crépeau, V., Cambon-Bonavita, M. A., Lesongeur, F., Randrianavelo, H., Sarradin, P. M., Sarrazin, J., and Godfroy, A.: Diversity and function in microbial mats from the Lucky Strike hydrothermal vent field, FEMS Microbiol. Ecol., 76, 524-540, 2011.

Cunha, M. R, Patterson, G. L. J., Amaro, T., Blackbird, S., de Stitger, H. C., Ferreira, C., Glover, A., Hilario, A., Kiriakoulakis, K., Neal, L., Ravara, A., Rodrigues, C. F., Tiago, A., and Billett, D. S. M.: Biodiversity of macrofaunal assemblages from three Portuguese submarine canyons (NE Atlantic), Deep-Sea Res. II, 58, 2433-2447, 2011.

Cunha, M. R., Rodrigues, C. F., Génio, L., Hilário, A., Ravara, A., and Pfannkuche, O.: Macrofaunal assemblages from mud volcanoes in the Gulf of Cadiz: abundance, biodiversity and diversity partitioning across spatial scales, Biogeosciences, 10, 25532568, doi:10.5194/bg-10-2553-2013, 2013.

Dando, P. R. and Spiro, B.: Varying nutritional dependence of the thyasirid bivalves Thyasira sarsi and T. equalis on chemoautotrophic symbiotic bacteria, demonstrated by isotope ratios of tissue carbon and shell carbonate, Mar. Ecol.-Prog. Ser., 92, 151158, 1993.

Dando, P. R., Southward, A. J., Southward, E. C., Terwilliger, N. B., and Terwilliger, R. C.: Sulphur-oxidizing bacteria and haemoglobin in gills of the bivalve mollusc Myrtea spinifera, Mar. Ecol.-Prog. Ser., 23, 85-98, 1985.

Dando, P. R., Southward, A. J., and Southward, E. C.: Chemoautotrophic symbionts in the gills of the bivalve mollusc Lucinoma borealis and the sediments chemistry of its habitat, P. Roy. Soc. Lond. B, 227, 227-247, 1986.

Dando, P. R., Dixon, D. R., Southward, A. J., Southward, E. C., Crawford, A., and Crawford, M.: Shipwrecked tube worms, Nature 356, p. 667, 1992.
Dando, P., Bussmann, I., Niven, S., Ohara, S., Schmaljohann, R., and Taylor, L.: A methane seep area in the Skagerrak, the habitat of the pogonophore Siboglinum poseidoni and the bivalve mollusk Thyasira sarsi, Mar. Ecol.-Prog. Ser., 107, 157-167, 1994.

De Beer, D., Sauter, E., Niemann, H., Kaul, N., Foucher, J. P., Witte, U., Schluter, M., and Boetius, A.: In situ fluxes and zonation of microbial activity in surface sediments of the Hakon Mosby Mud Volcano, Limnol. Oceanogr., 51, 1315-1331, 2006.

DeChaine, E. G., Bates, A. E., Shank, T., and Cavanaugh, C. M.: Off-axis symbiosis found: characterization and biogeography of bacterial symbionts of Bathymodiolus mussels from Lost City hydrothermal fields, Environ. Microbiol., 8, 1902-1912, 2006.

Decker, C. and Olu, K.: Habitat heterogeneity influences cold-seep macrofaunal communities within and among seeps along the Norwegian margin - Part 2: contribution of chemosynthesis and nutritional patterns, Mar. Ecol.-Evol. Persp., 33, 231-245, 2012.

Decker, C., Olu, K., Cunha, R. L., and Arnaud-Haond, S.: Phylogeny and diversification patterns among vesicomyid bivalves, PLoS One, 7, e33359, doi:10.1371/journal.pone.0033359, 2012.

Decker C, Olu, K., Arnaud-Haond, S., and Duperrons, S.: Physical proximity may promote lateral acquisition bacterial symbionts in vesicomyid clams, PLoS One, in press, 2013.

Desbruyères, D., Almeida, A., Biscoito, M., Comtet, T., Khripounoff, A., Le Bris, N., Sarradin, P. M., and Segonzac, M.: A review of the distribution of hydrothermal vent communities along the northern Mid-Atlantic Ridge: dispersal vs. environmental controls, Hydrobiologia, 440, 201-216, 2000.

Distel, D. L. and Felbeck, H.: Endosymbiosis in the lucinid clams Lucinoma aequizonata, Lucinoma annulata and Lucina floridana - a reexamination of the functional morphology of the gills as bacteria-bearing organs, Mar. Biol., 96, 79-86, 1987.

Distel, D. L. and Wood, A. P.: Characterization of the gill symbiont of Thyasira flexuosa (Thyasiridae: Bivalvia) by use of the polymerase chain reaction and $16 \mathrm{~S}$ rRNA sequence analysis, J. Bacteriol., 174, 6317-6320, 1992.

Distel, D. L., Lane, D., Olsen, G., Giovannoni, S., Pace, B., Pace, N., Stahl, D., and Felbeck, H.: Sulfur-oxidizing bacterial endosymbionts - Analysis of phylogeny and specificity by $16 \mathrm{~S}$ ribosomal RNA sequences, J. Bacteriol., 170, 2506-2510, 1988.

Distel, D. L., Felbeck, H., and Cavanaugh, C.: Evidence for phylogenetic congruence among sulfur-oxidizing chemoautotrophic bacterial endosymbionts and their bivalve host, J. Mol. Evol., 38, 533-542, 1994.

Distel, D. L., Lee, H. K. W., and Cavanaugh, C. M.: Intracellular coexistence of methano- and thioautotrophic bacteria in a hydrothermal vent mussel, P. Natl. Acad. Sci. USA, 92, 9598-9602, 1995.

Distel, D. L., Baco, A., Chuang, E., Morrill, W., Cavanaugh, C., and Smith, C.: Do mussels take wooden steps to deep-sea vents?, Nature, 403, 725-726, 2000.

Dixon, D. R., Lowe, D. M., Miller, P. I., Villemin, G. R., Colaco, A., Serrão-Santos, R., and Dixon, L. R. J. Evidence of seasonal reproduction in the Atlantic vent mussel Bathymodiolus azoricus, and an apparent link with the timing of photosynthetic primary production, J. M. Biol. Assoc. UK, 86, 1363-1371, 2006.

Douglas, A. E.: Symbiotic interactions, Oxford University Press, Oxford, 1994.

Dubilier, N., Windoffer, R., and Giere, O.: Ultrastructure and stable carbon isotope composition of the hydrothermal vent mussel 
Bathymodiolus brevior and $B$. sp. affinis brevior from the North Fiji Basin, western Pacific, Mar. Ecol.-Prog. Ser., 165, 187-193, 1998.

Dubilier, N., Bergin, C., and Lott, C.: Symbiotic diversity in marine animals: the art of harnessing chemosynthesis, Nat. Rev. Microbiol., 6, 725-740, 2008.

Dufour, S. C.: Gill anatomy and the evolution of symbiosis in the bivalve family Thyasiridae, Biol. Bull., 208, 200-212, 2005.

Dufour, S. C. and Felbeck, H.: Sulphide mining by the superextensile foot of symbiotic thyasirid bivalves, Nature, 426, 65-67, 2003.

Dufour, S. C. and Felbeck, H.: Symbiont abundance in thyasirids (Bivalvia) is related to particulate food and sulphide availability, Mar. Ecol.-Prog. Ser., 320, 185-194, 2006.

Duggen, S., Hoernle, K., van den Bogaard, P., Rupke, L., and Morgan, J. P.: Deep roots of the Messinian salinity crisis, Nature, 422, 602-606, 2003.

Duperron, S.: The diversity of deep-sea mussels and their bacterial symbioses, in: The Vent and Seep biota, edited by: Kiel, S., 137167, Springer, 2010.

Duperron, S., Nadalig, T., Caprais, J. C., Sibuet, M., Fiala-Médioni, A., Amann, R., and Dubilier, N.: Dual symbiosis in a Bathymodiolus mussel from a methane seep on the Gabon continental margin (South East Atlantic): 16S rRNA phylogeny and distribution of the symbionts in the gills, Appl. Environ. Microbiol., 71, 1694-1700, 2005.

Duperron, S., Fiala-Médioni, A., Caprais, J. C., Olu, K., and Sibuet, M.: Evidence for chemoautotrophic symbiosis in a Mediterranean cold seep clam (Bivalvia: Lucinidae): comparative sequence analysis of bacterial 16S rRNA, APS reductase and RubisCO genes, FEMS Microbiol. Ecol., 59, 64-70, 2007a.

Duperron, S., Sibuet, M., MacGregor, B. J., Kuypers, M. M., Fisher, C. R., and Dubilier, N.: Diversity, relative abundance, and metabolic potential of bacterial endosymbionts in three Bathymodiolus mussels (Bivalvia: Mytilidae) from cold seeps in the Gulf of Mexico, Environ. Microbiol., 9, 1423-1438, $2007 \mathrm{~b}$.

Duperron, S., Halary, S., Lorion, J., Sibuet, M., and Gaill, F.: Unexpected co occurence of 6 bacterial symbionts in the gill of the cold seep mussel Idas sp. (Bivalvia: Mytilidae), Environ. Microbiol., 10, 433-445, 2008a.

Duperron, S., Laurent, M. C. Z., Gaill, F., and Gros, O.: Sulphuroxidizing extracellular bacteria in the gills of Mytilidae associated with wood falls, FEMS Microbiol. Ecol., 63, 338-349, 2008b.

Duperron, S., Lorion, J., Samadi, S., Gros, O., and Gaill, F.: Symbioses between deep-sea mussels (Mytilidae: Bathymodiolinae) and chemosynthetic bacteria: diversity, function and evolution, C. R. Biol., 332, 298-310, 2009.

Duperron, S., Guezi, H., Gaudron, S. M., Pop Ristova, P., Wenzhöfer, F., and Boetius, A.: Relative abundances of methaneand sulphur-oxidizing symbionts in the gills of a cold seep mussel and link to their potential energy sources, Geobiology, 9, 481491, 2011.

Duperron, S., Rodrigues, C. F., Léger, N., Szafranski, K. M., Decker, C., Olu, K., and Gaudron, S. M.: Diversity of symbioses between chemosynthetic bacteria and metazoans at the Guiness cold seep site (Gulf of Guinea, West Africa), Microbiol. Open, 1, 467-480, 2012.
Duplessis, M. R., Ziebis, W., Gros, O., Caro, A., Robidart, J., and Felbeck, H.: Respiration strategies utilized by the gill endosymbiont from the host lucinid Codakia orbicularis (Bivalvia: Lucinidae), Appl. Environ. Microbiol., 70, 4144-4150, 2004.

Durand, P. and Gros, O.: Bacterial host specificity of Lucinacea endosymbionts: interspecific variation in $16 \mathrm{~S}$ rRNA sequences, FEMS Microbiol. Lett., 140, 193-198, 1996.

Durand, P., Gros, O., Frenkiel, L., and Prieur, D.: Phylogenetic characterization of sulfur-oxidizing bacterial endosymbionts in three tropical Lucinidae by $16 \mathrm{~S}$ rDNA sequence analysis, Mol. Mar. Biol. Biotechnol., 5, 37-42, 1996.

Eisen, J. A., Smith, S. W., and Cavanaugh, C. M.: Phylogenetic relationships of chemoautotrophic bacterial symbionts of Solemya velum Say (Mollusca: Bivalvia) determined by $16 \mathrm{~S}$ rRNA gene sequence analysis, J. Bacteriol., 174, 3416-3421, 1992.

Elsaied, H. E., Kaneko, R., and Naganuma, T.: Molecular characterization of a deep-sea methanotrophic mussel symbiont that carries a RuBisCO gene, Mar. Biotechnol., 8, 511-520, 2006.

Endow, K. and Ohta, S.: Occurence of bacteria in the primary oocytes of vesicomyid clam Calyptogena soyoae, Mar. Ecol.Prog. Ser., 64, 309-317, 1990.

Felbeck, H., Childress, J. J., and Somero, G. N.: Calvin-Benson cycle and sulphide oxidation enzymes in animals from suplhiderich habitats, Nature, 293, 291-293, 1981.

Fiala-Médioni, A. and Le Pennec, M.: Trophic structural adaptations in relation with the bacterial association of Bivalve molluscs from hydrothermal vents and subduction zones, Symbiosis, 4, 63-74, 1987.

Fiala-Médioni, A., McKiness, Z. P., Dando, P., Boulegue, J., Mariotti, A., Alayse-Danet, A. M., Robinson, J. J., and Cavanaugh, C. M.: Ultrastructural, biochemical and immunological characterisation of two populations of he Mytilid mussel Bathymodiolus azoricus from the Mid Atlantic Ridge: evidence for a dual symbiosis, Mar. Biol., 141, 1035-1043, 2002.

Fisher, C. R.: Chemoautotrophic and methanotrophic symbioses in marine invertebrates, Rev. Aquat. Sci., 2, 399-436, 1990.

Fisher, C. R.: Oxidation of methane by deep-sea Mytilids in the Gulf of Mexico, in: Biochemistry of global change: Radiatively active trace gases, edited by: Oremland, R. S., Chapman \& Hall, New York, 606-618, 1993.

Fisher, C. R., Childress, J. J., Arp, A. J., Brooks, J. M., Distel, D. L., Favuzzi, J. A., Felbeck, H., Hessler, R., Johnson, K. S., Kennicutt, M. C., Macko, S. A., Newton, A., Powell, M. A., Somero, G. N., and Soto, T.: Microhabitat variation in the hydrothermal vent mussel, Bathymodiolus thermophilus, at the Rose Garden vent on the Galapagos Rift, Deep-Sea Res., 35, 1769-1791, 1988.

Fisher, C. R., Brooks, J. M., Vodenichar, J. S., Zande, J. M., Childress, J. J., and Burke Jr., R. A.: The co-occurence of methanotrophic and chemoautotrophic sulfur oxidizing bacterial symbionts in a deep-sea mussel, Mar. Ecol., 14, 277-289, 1993.

Frenkiel, L. and Moueza, M.: Gill ultrastructure and symbiotic Bacteria in Codakia orbicularis (bivalvia, Lucinidae), Zoomorphology, 115, 51-61, 1995.

Frenkiel, L., Gros, O., and Moueza, M.: Gill structure in Lucina pectinata (Bivalvia: Lucinidae) with reference to hemoglobin in bivalves with symbiotic sulphur-oxidizing bacteria, Mar. Biol., 125, 511-524, 1996.

Fujiwara, Y., Kato, C., Masui, N., Fujikura, K., and Kojima, S.: Dual symbiosis in the cold-seep thyasirid clam Maorithyas hadalis 
from the hadal zone in the Japan Trench, western Pacific, Mar. Ecol.-Prog. Ser., 214, 151-159, 2001.

Gaudron, S. M., Pradillon, F., Pailleret, M., Duperron, S., Le Bris, N., and Gaill, F.: Colonization of organic substrates deployed in deep-sea reducing habitats by symbiotic species and associated fauna, Mar. Environ. Res., 70, 1-12, 2010.

Gaudron, S. M., Demoyencourt, E., and Duperron, S.: Reproductive traits of the cold seep mussel Idas modiolaeformis: from gametogenesis to larval dispersal, Biol. Bull., 222, 6-16, 2012.

Gebruk, A. V., Krylova, E. M., Lein, A. Y., Vinogradov, G. M., Anderson, E., Pimenov, N. V., Cherkashev, G. A., and Crane, K.: Methane seep community of the Hakon Mosby mud volcano (the Norwegian Sea): composition and trophic aspects, Sarsia, 88, 394-403, 2003.

Gebruk, A. V., Fabri, M. C., Briand, P., and Desbruyères, D.: Community dynamics over a decadal scale at Logatchev, $14^{\circ} 45^{\prime} \mathrm{N}$, Mid-Atlantic Ridge, Cah. Biol. Mar., 51, 383-388, 2010.

Génio, L., Johnson, S. B., Vrijenhoek, R. C., Cunha, M. R., Tyler, P. A., Kiel, S., and Little, C. T. S.: New record of "Bathymodiolus" mauritanicus Cosel 2002 from the Gulf of Cadiz (NE Atlantic) mud volcanoes, J. Shellfish Res., 27, 53-61, 2008.

German, C. R., Ramirez-Llodra, E., Baker, M. C., Tyler, P. A., and the Chess Scientific Steering Committee: deep-water chemosynthetic ecosystem research during the Census of Marine Life decade and beyond: a proposed deep-ocean road map, PLoS ONE, 6, e23259, doi:10.1371/journal.pone.0023259, 2011.

Gil, R., Latorre, A., and Moya, A.: Bacterial endosymbionts of insects: insights from comparative genomics, Environ. Microbiol., 6, 1109-1122, 2004.

Goffredi, S. K. and Barry, J. P.: Species-specific variation in sulfide physiology between closely related Vesicomyid clams, Mar. Ecol. Prog. Ser., 225, 227-238, 2002.

Gracia, A., Rangel-Buitrago, N., and Sellanes, J.: Methane seep molluscs from the Sinu-San Jacinto fold belt in the Caribbean Sea of Colombia, J. Mar. Biol. Assoc. UK, 92, 1367-1377, 2012.

Gros, O. and Gaill, F.: Extracellular bacterial association in gills of "wood mussels," Cah. Biol. Mar., 48, 103-109, 2007.

Gros, O., Darrasse, A., Durand, P., Frenkiel, L., and Mouëza, M.: Environmental transmission of a sulfur-oxidizing bacterial gill endosymbiont in the tropical lucinid bivalve Codakia orbicularis, Appl. Environ. Microbiol., 62, 2324-2330, 1996.

Gros, O., Frenkiel, L., and Moueza, M.: Embryonic, larval, and post-larval development in the symbiotic clam Codakia orbicularis (Bivalvia: Lucinidae), Invertebr. Biol., 116, 86-101, 1997.

Gros, O., Duplessis, M. R., and Felbeck, H.: Embryonic development and endosymbiont transmission mode in the symbiotic clam Lucinoma aequizonata (Bivalvia: Lucinidae), Invertebr. Reprod. Dev., 36, 93-103, 1999.

Gros, O., Liberge, M., and Felbeck, H.: Interspecific infection of aposymbiotic juveniles of Codakia orbicularis by various tropical lucinid gill-endosymbionts, Mar. Biol., 142, 57-66, 2003a.

Gros, O., Liberge, M., Heddi, A., Kherchadourian, C., and Felbeck, H.: Detection of the free-living forms of sulfide-oxidizing gill endosymbionts in the lucinid habitat (Thalassia testudinum environment), Appl. Environ. Microbiol., 69, 6254-6257, 2003b.

Gros, O., Elisabeth, N. H., Gustave, S. D. D., Caro, A., and Dubilier, N.: Plasticity of symbiont acquisition throughout the life cycle of the shallow-water tropical lucinid Codakia orbiculata (Mollusca: Bivalvia), Environ. Microbiol., 14, 1584-1595, 2012.
Gustafson, R. and Lutz, R.: Larval and early postlarval development of the protobranch bivalve Solemya velum (mollusca, Bivalvia), J. Mar. Biol. Assoc. UK, 72, 383-402, 1992.

Gustafson, R., Turner, R., Lutz, R., and Vrijenhoek, R.: A new genus and five new species of mussels (Bivavlia, Mytilidae) from deep-sea sulfide/hydrocarbon seeps in the Gulf of Mexico, Malacologia, 40, 63-112, 1998.

Gustafson, R. G. and Reid, R. G. B.: Association of bacteria with larvae of the gutless protobranch bivalve Solemya reidi (Cryptodonta: Solemyidae), Mar. Biol., 97, 389-401, 1988.

Halary, S., Riou, V., Gaill, F., Boudier, T., and Duperron, S.: 3D FISH for the quantification of methane- and sulphur-oxidising endosymbionts in bacteriocytes of the hydrothermal vent mussel Bathymodiolus azoricus, ISME J., 2, 284-292, 2008.

Herry, A., Diouris, M., and Lepennec, M.: Chemoautotrophic symbionts and translocation of fixed carbon from bacteria to host tissues in the littoral bivalve Loripes lucinalis (lucinidae), Mar. Biol., 101, 305-312, 1989.

Imhoff, J. F., Sahling, H., Süling, J., and Kath, T.: 16S rDNA-based phylogeny of sulphur-oxidizing bacterial endosymbionts in marine bivalves from cold-seep habitats, Mar. Ecol.-Prog. Ser., 249, 39-51, 2003.

Ivanov, M., Mazzini, A., Blinova, V., Kozlova, E., Laberg, J.-S., Matveeva, T., Taviani, M., and Kaskov, N.: Seep mounds on the Southern Vøring Plateau (offshore Norway), Mar. Petrol. Geol., 27, 1235-1261, 2010.

Johnson, M. A. and Fernandez, C.: Bacterial symbiosis in Loripes lucinalis (Mollusca: Bivalvia) with comments on reproductive strategy, J. Mar. Biol. Assoc. UK, 81, 251-257, 2001.

Johnson, M. A., Fernandez, C., and Pergent, G.: The ecological importance of an invertebrate chemoautotrophic symbiosis to phanerogam seagrass beds, Bull. Mar. Sci., 71, 1343-1351, 2002.

Jollivet, D., Faugeres, J., Griboulard, R., Desbruyeres, D., and Blanc, G.: Composition and spatial organization of a cold seep community on the South Barbados Accretionary Prism - tectonic, geochemical and sedimentary context, Prog. Oceanogr., 24, 25-45, 1990.

Jones, W. J., Won, Y. J., Maas, P. A. Y., Smith, P. J., Lutz, R. A., and Vrijenhoek, R. C.: Evolution of habitat use by deep-sea mussels, Mar. Biol., 148, 841-851, 2006.

Kadar, E., Bettencourt, R., Costa, V., Serrão Santos, R., Lodo-daCunha, A., and Dando, P. R.: Experimentally induced endosymbiont loss and re-acquirement in the hydrothermal vent bivalve Bathymodiolus azoricus, J. Exp. Mar. Biol. Ecol., 318, 99-110, 2005.

Kegwin, L. D.: Pliocene closing of the Isthmus of Panama, based on biostratigraphic evidence from nearby Pacific Ocean and Caribbean Sea cores, Geology, 6, 630-634, 1978.

Kenk, V. C. and Wilson, B. R.: A new mussel (Bivlavia: Mytilidae) from hydrothermal vents in the Galapagos Rift zone, Malacologia, 26, 253-271, 1985.

Kleiner, M., Petersen, J. M., and Dubilier, N.: Convergent and divergent evolution of metabolism in sulfur-oxidizing symbionts and the role of horizontal gene transfer, Curr. Opin. Microbiol., 15, 621-631, 2012.

Krueger, D. M. and Cavanaugh, C. M.: Phylogenetic diversity of bacterial symbionts of Solemya hosts based on comparative sequence analysis of 16S rRNA genes, Appl. Environ. Microbiol., 63, 91-98, 1997. 
Krueger, D. M., Gallager, S., and Cavanaugh, C. M.: Suspension feeding on phytoplankton by Solemya velum, a symbiontcontaining clam, Mar. Ecol.-Prog. Ser., 86, 145-151, 1992.

Krueger, D. M., Dubilier, N., and Cavanaugh, C. M.: Chemoautotrophic symbiosis in the tropical clam Solemya occidentalis (Bivalvia: Protobranchia): Ultrastructural and phylogenetic analysis, Mar. Biol., 126, 55-64, 1996a.

Krueger, D. M., Gustafson, R. G., and Cavanaugh, C. M.: Vertical transmission of chemoautotrophic symbionts in the bivalve Solemya velum (Bivalvia: Protobranchia), Biol. Bull., 190, 195-202, 1996b.

Krylova, E. and Cosel, R. V.: A new genus of large Vesicomyidae (Mollusca, Bivalvia, Vesicomyidae, Pliocardiinae) from the Congo margin, with the first record of the subfamily Pliocardiinae in the Bay of Biscay (northeastern Atlantic), Zoosystema, 33, 83-99, 2011

Krylova, E. M. and Sahling, H.: Vesicomyidae (Bivalvia): Current taxonomy and distribution, PLoS One, 5, e9957, doi:10.1371/journal.pone.0009957, 2010.

Krylova, E. M., Sahling, H., and Janssen, R.: Abyssogena: a new genus of the family Vesicomyidae (Bivalvia) from deep-water vents and seeps, J. Molluscan Stud., 76, 107-132, 2010.

Kuwahara, H., Yoshida, T., Takaki, Y., Shimamura, S., Nishi, S., Harada, M., Matsuyama, K., Takishita, K., Kawato, M., Uematsu, K., Fujiwara, Y., Sato, M., Kato, C., Kitagawa, M., Kato, I., and Maruyama, A.: Reduced genome of the thioautotrophic intracellular symbiont in a deep-sea clam, Calyptogena okutanii, Curr. Biol., 17, 881-886, 2007.

Le Bris, N. and Duperron, S.: Chemosynthetic communities and biogeochemical energy pathways along the MAR: the case of Bathymodiolus azoricus, in: Diversity of hydrothermal systems on slow spreading ocean ridges, edited by: Rona, P. A., Devey, C. W., Dyment, J., and Murton, B. J., American Geophysical Union, 409-429, 2010.

Le Goff-Vitry, M. C., Chipman, A. D., and Comtet, T.: In situ hybridization on whole larvae: a novel method for monitoring bivalve larvae, Mar. Ecol.-Prog. Ser., 343, 161-172, 2007.

Le Pennec, M. and Beninger, P. G.: Reproductive characteristics and strategies of reducing-system bivalves, Comp. Bioch. Physiol. A, 126, 1-16, 2000.

Le Pennec, M., Herry, A., Lutz, R. A., and Fiala-Médioni, A.: First ultrastructural observations of the gill of a deep-sea hydrothermal Pectinid Bivalve, C. R. Acad. Sci., 307, 627-633, 1988.

Lee, R. W., Robinson, J. J., and Cavanaugh, C. M.: Pathways of inorganic nitrogen assimilation in chemoautotrophic bacteriamarine invertebrate symbioses: expression of host and symbiont glutamine synthetase, J. Exp. Biol., 202, 289-300, 1999.

Lisin, S. E., Hannan, E. E., Kochevar, R. E., Harrold, C., and Barry, J. P.: Temporal variation in gametogenic cycles of vesicomyid clams, Invertebr. Reprod. Dev., 31, 307-318, 1997.

Little, C. T. S. and Vrijenhoek, R. C.: Are hydrothermal vent animals living fossils?, Trends Ecol. Evol., 18, 582-588, 2003.

Lonsdale, P.: Clustering of suspension-feeding macrobenthos near abyssal hydrothermal vents at oceanic spreading centers, DeepSea Res., 24, 857-863, 1977.

Lorion, J. and Samadi, S.: Species richness, sampling bias and phylogenetics in deep-sea mussels, Cah. Biol. Mar., 51, 435-439, 2010 .
Lorion, J., Duperron, S., Gros, O., Cruaud, C., Couloux, A., and Samadi, S.: Several deep-sea mussels and their associated symbionts are able to live both on wood and on whale falls, P. Roy. Soc. Lond. B, 276, 177-185, 2009.

Lorion, J., Buge, B., Cruaud, C., and Samadi, S.: New insights into diversity and evolution of deep-sea Mytilidae (Mollusca: Bivalvia), Mol. Phyl. Evol., 57, 71-83, 2010.

Lorion, J., Halary, S., do Nascimento, J., Samadi, S., Couloux, A., and Duperron, S.: Evolutionary history of Idas sp. Med, (Bivalvia: Mytilidae), a cold seep mussel bearing multiple symbionts, Cah. Biol. Mar., 53, 77-87, 2012.

Lutz, R. A., Jablonski, D., Rhoads, D. C., and Turner, R.: Larval dispersal of a deep-sea hydrothermal vent bivalve from the Galapagos rift, Mar. Biol., 57, 127-133, 1980.

Martins, I., Colaço, A., Dando, P. R., Martins, I., Desbruyères, D., Sarradin, P. M., Marques, J. C., and Serrão Santos, R.: Sizedependant variations on the nutritional pathway of Bathymodiolus azoricus demonstrated by a C-flux model, Ecol. Modelling, 217, 59-71, 2008.

Miyazaki, J. I., De Oliveira Martins, L., Fujita, Y., Matsumoto, H., and Fujiwara, Y.: Evolutionary process of deep-sea Bathymodiolus mussels, PLoS one, 5, e10363, doi:10.1371/journal.pone.0010363, 2010.

Nelson, D. C., Hagen, K. D., and Edwards, D. B.: The gill symbiont of the hydrothermal vent mussel Bathymodiolus thermophilus is a psychrophilic, chemoautotrophic, sulfur bacterium, Mar. Biol., 121, 487-495, 1995.

Newton, I. L. G., Woyke, T., Auchtung, T. A., Dilly, G. F., Dutton, R. J., Fisher, M. C., Fontanez, K. M., Lau, E., Steward, F. J., Richardson, P. M., Barry, K. W., Saunders, E., Detter, J. C., Wu, D., Eisen, J. A., and Cavanaugh, C. M.: The Calyptogena magnifica chemoautotrophic symbiont genome, Science, 315, 9981000, 2007.

Ockelmann, K.: Developmental types in marine Bivalves and their distribution along the Atlantic coast of Europe, in Proceedings of the first European Malacology Congress 1962, Malacological Society of London, London, 25-35, 1965.

Ockelmann, K. W. and Dinesen, G. E.: Life on wood - the carnivorous deep-sea mussel Idas argenteus (Bathymodiolinae, Mytilidae, Bivalvia), Mar. Biol. Res., 7, 71-84, 2011.

Oliver, P. G. and Holmes, A. M.: New species of Thyasiridae (Bivalvia) from chemosynthetic communities in the Atlantic Ocean, J. Conchol., 39, 175-183, 2006.

Oliver, P. G. and Taylor, J. D.: Bacterial Symbiosis in the Nucinellidae (bivalvia: Solemyida) with Descriptions of Two New Species, J. Molluscan Stud., 78, 81-91, 2012.

Oliver, P. G., Rodrigues, C. F., and Cunha, M. R.: Chemosymbiotic bivalves from the mud volcanoes of the Gulf of Cadiz, NE Atlantic, with descriptions of new species of Solemyidae, Lucinidae and Vesicomyidae, ZooKeys, 113, 1-38, 2011.

Oliver, P. G., Southward, E. C., and Dando, P. R.: Bacterial symbiosis in Syssitomya pourtalesiana Oliver, 2012 (Galeommatoidea: Montacutidae), a bivalve commensal with the deep-sea echinoid Pourtalesia, J. Molluscan Stud., 79, 30-41, 2013.

Olu, K., SIbuet, M., Hermeignies, F., Foucher, J.-P., and FialaMédioni, A.: Spatial distribution of diverse cold seep communities living on various diapiric structures of the southern Barbados prism, Prog. Oceanog., 38, 347-376, 1996. 
Olu, K., Cordes, E. E., Fisher, C. R., Brooks, J. M., Sibuet, M., and Desbruyères, D.: Biogeography and potential exchanges among the Atlantic Equatorial Belt cold-seep faunas, PLoS one, 5, e11967, doi:10.1371/journal.pone.0011967, 2010.

Olu-LeRoy, K., Sibuet, M., Fiala-Médioni, A., Gofas, S., Salas, C., Mariotti, A., Foucher, J. P., and Woodside, J.: Cold seep communities in the deep eastern Mediterranean Sea: composition, symbiosis, and spatial distribution on mud volcanoes, Deep-Sea Res. I, 51, 1915-1936, 2004.

Olu-LeRoy, K., Caprais, J. C., Fifis, A., Fabri, M. C., Galéron, J., Budzinski, H., Le Ménach, K., Khripounoff, A., Ondréas, H., and Sibuet, M.: Coll seep assemblages on a giant pockmark off west Africa: spatial patterns and environmental control, Mar. Ecol., 28, 1-16, 2007a.

Olu-LeRoy, K., Cosel, R. V., Hourdez, S., and Jollivet, D.: AmphiAtlantic cold-seep Bathymodiolus species complexes across the equatorial belt, Deep-Sea Res., 54, 1890-1911, 2007 b.

Pailleret, M., Haga, T., Petit, P., Privé-Gill, C., Saedlou, N., Gaill, F., and Zbinden, M.: Sunken woods from the Vanuatu islands: identification of wood substrates and preliminary description of associated fauna, Mar. Ecol., 27, 1-9, 2007.

Parra, M., Sellanes, J., Dupre, E., and Krylova, E.: Reproductive characteristics of Calyptogena gallardoi (Bivalvia: Vesicomyidae) from a methane seep area off Concepcion, Chile, J. Mar. Biol. Assoc. UK, 89, 161-169, 2009.

Pastorelli, A. M., Rositani, L., De Zio, V., and Marano, G.: Rinvenimento di Adula simpsoni (Marshall, 1900) e Xylophaga dorsalis (Turton, 1819) - Mollusca Bivalvia - sul relitto della Kater I Rhades, Biologia Marina Mediterranea, 6, 418-420, 1999.

Paull, C., Hecker, B., Commeau, R., Freemanlynde, R., Neumann, C., Corso, W., Golubic, S., Hook, J., Sikes, E., and Curray, J.: Biological commnities at the Florida escarpment resemble hydrothermal vent taxa, Science, 226, 965-967, 1984.

Peek, A. S., Feldman, R. A., Lutz, R. A., and Vrijenhoek, R. C.: Cospeciation of chemoautotrophic bacteria and deep sea clams, P. Natl. Acad. Sci. USA, 95, 9962-9966, 1998a.

Peek, A. S., Vrijenhoek, R. C., and Gaut, B. S.: Accelerated evolutionary rate in sulfur oxidizing endosymbiotic Bacteria associated with the mode of symbiont transmission, Mol. Biol. Evol., 15, 1514-1523, $1998 b$.

Pelorce J. and Poutiers J.-M.: Une nouvelle espèce de Bathymodiolinae (Mollusca, Bivalvia, Mytilidae) associée à des os de baleine coulés en Méditerranée, Zoosystema, 31, 975-985, 2009.

Pernthaler, A. and Amann, R.: Simultaneous fluorescence in situ hybridization of mRNA and rRNA in environmental bacteria, Appl. Environ. Microbiol., 70, 5426-5433, 2004.

Petersen, J. M., Zielinski, F. U., Pape, T., Seifert, R., Moraru, C., Amann, R., Hourdez, S., Girguis, P. R., Wankel, S. D., Barbe, V., Pelletier, E., Fink, D., Borowski, C., Bach, W., and Dubilier, N.: Hydrogen is an energy source for hydrothermal vent symbioses, Nature, 476, 176-180, 2011.

Petersen, J. M., Wentrup, C., Verna, C., Knittel, K., and Dubilier, N.: Origins and evolutionary flexibility of chemosynthetic symbionts from deep-sea animals, Biol. Bull., 223, 123-137, 2012.

Pimenov, N. V., Kalyuzhnaya, M. G., Khmelenina, V. N., Mityushina, L. L., and Trotsenko, Y. A.: Utilization of methane and carbon dioxide by symbiotrophic bacteria in gills of Mytilidae (Bathymodiolus) from the Rainbow and Logatchev hydrothermal dields on the Mid-Atlantic Ridge, Microbiology, 71, 587-594,
2002.

Pradillon, F., Schmidt, A., Peplies, J., and Dubilier, N.: Species identification of marine invertebrate early stages by whole-larvae in situ hybridisation of $18 \mathrm{~S}$ ribosomal RNA, Mar. Ecol.-Prog. Ser., 333, 103-116, 2007.

Raggi, L., Schubotz, F., Hinrichs, K.-U., Dubilier, N., and Petersen J. M.: Bacterial symbionts of Bathymodiolus mussels and Escarpia tubeworms from Chapopote, an asphalt seep in the southern Gulf of Mexico, Environ. Microbiol., doi:10.1111/1462 2920.12051, 2012.

Rau, G. and Hedges, J.: C-13 depletion in a hydrothermal vent mussel - Suggestion of a chemo-synthetic food source, Science, 203, 648-649, 1979.

Riou, V., Halary, S., Duperron, S., Bouillon, S., Elskens, M., Bettencourt, R., Santos, R. S., Dehairs, F., and Colaço, A.: Influence of $\mathrm{CH}_{4}$ and $\mathrm{H}_{2} \mathrm{~S}$ availability on symbiont distribution, carbon assimilation and transfer in the dual symbiotic vent mussel Bathymodiolus azoricus, Biogeosciences, 5, 1681-1691, doi:10.5194/bg-5-1681-2008, 2008.

Riou, V., Colaco, A., Bouillon, S., Khripounoff, A., Dando, P., Mangion, P., Chevalier, E., Korntheuer, M., Santos, R. S., and Dehairs, F.: Mixotrophy in the deep sea: a dual endosymbiotic hydrothermal mytilid assimilates dissolved and particulate organic matter, Mar. Ecol.-Prog. Ser., 405, 187-201, 2010.

Ritt, B., Sarrazin, J., Caprais, J.-C., Noël, P., Gauthier, O., Pierre, C., Henry, P., and Desbruyères, D.: First insights into the structure and environmental setting of cold-seep communities in the Marmara Sea, Deep Sea Res. I, 57, 1120-1136, 2010.

Ritt, B., Duperron, S., Lorion, J., Sara Lazar, C., and Sarrazin, J.: Integrative study of a new cold-seep mussel (Mollusca: Bivalvia) associated with chemosynthetic symbionts in the Marmara Sea, Deep Sea Res. I, 67, 121-132, 2012.

Robinson, J. J. and Cavanaugh, C. M.: Expression of form I and form II Rubisco in chemoautotrophic symbioses: Implications for the interpretation of stable carbon isotope values, Limnol. Oceanogr., 40, 1496-1502, 1995.

Rodrigues, C. F. and Duperron, S.: Distinct symbiont lineages in three thyasirid species (Bivalvia: Thyasiridae) form the eastern Atlantic and Mediterranean Sea, Naturwissenschaften, 98, 281287, 2011.

Rodrigues, C. F., Webster, G., Cunha, M. R., Duperron, S., and Weightman, A. J.: Chemosynthetic bacteria found in bivalve species from mud volcanoes of the Gulf of Cadiz, FEMS Microbiol. Ecol., 73, 486-499, 2010.

Rodrigues, C. F., Duperron, S., and Gaudron, S. M.: First documented record of a living solemyid in a pockmark of the Nile deep-sea fan (eastern Mediterranean Sea), Mar. Biodiv. Rec., 4, e10, doi:10.1017/S175526721100008X, 2011.

Rodrigues, C., Cunha, M., Olu, K., and Duperron, S.: The smaller vesicomyid bivalves in the genus Isorropodon (Bivalvia, Vesicomyidae, Pliocardiinae) also harbour chemoautotrophic symbionts, Symbiosis, 56, 129-137, 2012.

Rodrigues, C. F., Cunha, M. R., Génio, L., and Duperron, S.: A complex picture of associations between two host mussels and symbiotic bacteria in the Northeast Atlantic, Naturwissenschaften, 100, 12-31, 2013.

Sahling, H., Bohrmann, G., Spiess, V., Bialas, J., Breitzke, M., Ivanov, M. V., Kasten, S., Krastel, S., and Schneider, R.: Pockmarks in the northern Congo fan area, SW Africa: complex 
seafloor features shaped by fluid flow, Mar. Geol., 249, 206-225, 2008.

Salas, C. and Gofas, S.: Brooding and non-brooding Dacrydium (Bivalvia: Mytilidae): A review of the Atlantic species, J. Molluscan Stud., 63, 261-283, 1997.

Salas, C. and Woodside, J.: Lucinoma kazani n. sp. (Mollusca: Bivalvia): evidence of a living benthic community associated with a cold seep in the Eastern Mediterranean Sea, Deep-Sea Res. I, 49, 991-1005, 2002.

Salerno, J. L., Macko, S. A., Hallam, S. J., Bright, M., Won, Y., McKiness, Z. P., and Van Dover, C. L.: Characterization of symbiont populations in life-history stages of mussels from chemosynthetic environments, Biol. Bull., 208, 145-155, 2005.

Samadi, S., Quéméré, E., Lorion, J., Tillier, A., Cosel, R. V., Lopez, P., Cruaud, C., Couloux, A., and Boisselier-Dubayle, M. C.: Molecular phylogeny in mytilids supports the wooden steps to deep-sea vents hypothesis, C. R. Acad. Sci., 330, 446-456, 2007.

Scheltema, R. S.: Larval dispersal as a means of genetic exchange between geographically separated populations of shallow-water benthic marine gastropods, Biol. Bull., 140, 284-322, 1971.

Schwedock, J., Hermer, T. L., Scott, K. M., Hektor, H. J., Seitz, A. P., Fontana, M. C., Distel, D. L., and Cavanaugh, C. M.: Characterization and expression of genes from the RubisCO gene cluster of the chemoautotrophic symbiont of Solemya velum: cbbLSQO, Arch. Microbiol., 182, 18-29, 2004.

Scott, K. M.: Allometry of gill weights, gill surface areas, and foot biomass d13C values of the chemoautotroph-bivalve symbiosis Solemya velum, Mar. Biol., 147, 935-941, 2005.

Scott, K. M. and Fisher, C. R.: Physiological ecology of sulfide metabolism in hydrothermal vent and coold seep vesicomyid clams and vestimentiferan tubeworms, Amer. Zool., 35, 102$111,1995$.

Smith, C. R. and Baco, A. R.: Ecology of whale falls at the deep-sea floor, Oceanogr. Mar. Biol. Ann. Rev., 41, 311-354, 2003.

Southward, E.: Gill symbionts in Thyasirids and other bivalve mollusks, J. Mar. Biol. Assoc. UK, 66, 889-914, 1986.

Southward, E. C.: The morphology of bacterial symbioses in the gills of mussels of the genera Adipicola and Idas (Bivalvia?: Mytilidae), J. Shellfish Res., 27, 139-146, 2008.

Southward, E. C. and Southward, A. J.: Virus-like particles in bacteria symbiotic in Bivalve gills, J. Mar. Biol. Assoc. UK, 71, 37-45, 1991.

Stewart, F. J. and Cavanaugh, C. M.: Bacterial endosymbioses in Solemya (Mollusca: Bivalvia) - model systems for studies of symbion-host adaptation, A. van Leeuwenhoek, 90, 343-360, 2006.

Stewart, F. J., Young, C. R., and Cavanaugh, C. M.: Lateral symbiont acquisition in a maternally transmitted chemosynthetic clam endosymbiosis, Mol. Biol. Evol., 25, 673-683, 2008.

Stewart, F. J., Baik, A. H. Y., and Cavanaugh, C. M.: Genetic subdivision of chemosynthetic endosymbionts of Solemya velum along the Southern New England Coast, Appl. Environ. Microbiol., 75, 6005-6007, 2009a.

Stewart, F. J., Young, C. R., and Cavanaugh, C. M.: Evidence for homologous recombination in intracellular chemosynthetic clam symbionts, Mol. Biol. Evol., 26, 1391-1404, 2009b.

Tamura, K., Peterson, D., Peterson, N., Stecher, G., Nei, M., and Kumar, S. MEGA5: Molecular Evolutionary Genetics Analysis using maximum likelihood, evolutionary distance, and maximum parsimony methods, Mol. Biol. Evol., 28, 2731-2739, 2011.

Taylor, J. D. and Glover, E.: Functional anatomy, chemosymbiosis and evolution of the Lucinidae, in: The evolutionary biology of the bivalvia, edited by: Harper, E. M., Taylor, J. D., and Crame, J. A., 207-225, Geological Society, London., 2000.

Taylor, J. D. and Glover, E.: Licinidae (Bivalvia) - the most diverse group of chemosymbioic molluscs, Zool. J. Linn. Soc., 148, 421438, 2006.

Taylor, J. D., Williams, S. T., and Glover, E. A.: Evolutionary relationships of the bivalve family Thyasiridae (Mollusca?: Bivalvia), monophyly and superfamily status, J. Mar. Biol. Assoc. UK, 87, 565-574, 2007.

Taylor, J. D., Glover, E. A., Smith, L., Dyal, P., and Williams, S. T.: Molecular phylogeny and classification of the chemosymbiotic bivalve family Lucinidae (Mollusca: Bivalvia), Zool. J. Linn. Soc., 163, 15-49, 2011.

Terwilliger, R. C., Terwilliger, M. B., and Arp, A.: Thermal vent clam (Calyptogena magnifica) hemoglobin, Science, 219, 981983, 1983.

Thorson, G.: Reproductive and larval ecology of marine bottom invertebrates, Biol. Rev. Cambridge Philos. Soc., 25, 1-45, 1950.

Tyler, P. A. and Young, C. M.: Reproduction and dispersal at vents and cold seeps, J. Mar. Biol. Assoc. UK, 79, 193-208, 1999.

Tyler, P. A., Young, C. M., Dolan, E., Arellano, S. M., Brooke, S. D., and Baker, M.: Gametogenic periodicity in the chemosynthetic cold-seep mussel "Bathymodiolus" childressi, Mar. Biol., 150, 829-840, 2007.

Van Der Heijden, K., Petersen, J. M., Dubilier, N., and Borowski, C.: Genetic connectivity between North and South Mid-Atlantic Ridge chemosynthetic bivalves and their symbionts, PLoS One, 7, e39994, doi:10.1371/journal.pone.0039994, 2012.

Van Dover, C. L., Aharon, P., Bernhard, J. M., Caylor, E., Doerris, M., Flickinger, W., Gilhooly, W., Goffredi, S. K., Kniwk, K. E., Macko, S. A., Rapoport, S., Raulfs, E. C., Ruppel, C., Salerno, S. L., Seitz, R. D., Sen Gupta, B. K., Shank, T., Turnipseed, M., and Vrijenhoek, R. C.: Blake Ridge methane seeps: characterization of a soft-sediment, chemosynthetically based ecosystem, DeepSea Res. I, 50, 281-300, 2003.

Ward, M. E., Shields, J. D., and Van Dover, C. L.: Parasitism in species of Bathymodiolus (Bivalvia: Mytilidae) mussels from deep-sea seep and hydrothermal vents, Dis. Aquat. Org., 62, 116, 2004.

Wenzhofer, F. and Glud, R. N.: Benthic carbon mineralization in the Atlantic: a synthesis based on in situ data from the last decade, Deep-Sea Res. I, 49, 1255-1279, 2002.

Wernegreen, J. J., Degnan, P. H., Lazarus, A. B., Palacios, C., and Bordenstein, S. R.: Genome evolution in insect cells: distinct features of an ant-bacterial relationship, Biol. Bull., 204, 221-231, 2003.

Williams, S. T., Taylor, J. D., and Glover, E.: Molecular phylogeny of the Lucinoidea (Bivalvia): nonmonophyly and separate acquisition of bacterial chemosymbiosis, J. Moll. Stud., 70, 187-202, 2004.

Won, Y., Young, C. R., Lutz, R. A., and Vrijenhoek, R. C.: Dispersal barriers and isolation among deep-sea mussel populations (Mytilidae: Bathymodiolus) from Eastern Pacific hydrothermal vents, Mar. Ecol., 12, 169-184, 2003.

Won, Y. J., Jones, W. J., and Vrijenhoek, R. C.: Absence of cospeciation between deep-sea mytilids and their thiotrophic symbionts, 
J. Shellfish Res., 27, 129-138, 2008.

Young, C. M., He, R., Emlet, R. B., Li, Y., Qian, H., Arellano, S. M., Van Gaest, A., Bennett, K. C., Wolf, M., Smart, T. I., and Rice, M. E.: Dispersal of deep-sea larvae from the intra-American seas: simulations of trajectories using Ocean models, Integr. Comp. Biol., 52, 483-496, 2012.
Zielinski, F. U., Pernthaler, A., Duperron, S., Raggi, L., Giere, O., Borowski, C., and Dubilier, N.: Widespread occurrence of an intranuclear bacterial parasite in vent and seep bathymodiolin mussels, Environ. Microbiol., 11, 1150-1167, 2009. 